This copy is the accepted version of the following article:

Blanco, J., B. Bellón, C. Fabricius, F. O. Roque, O. Pays, F. Laurent, H. Fritz, et P. Renaud. 2020. Interface processes between protected and unprotected areas: A global review and ways forward. Global Change Biology 26(3):1138-1154.https://doi.org/10.1111/gcb.14865

\title{
Interface processes between protected and unprotected areas: a global review and ways forward
}

Running head: Interface processes and protected areas

Julien Blanco $^{1, *}$, Beatriz Bellón ${ }^{1}$, Christo Fabricius ${ }^{2,3}$, Fabio de O. Roque ${ }^{4,5}$, Olivier Pays ${ }^{1,6}$, François Laurent $^{7}$, Hervé Fritz ${ }^{3,6,8}$, Pierre-Cyril Renaud ${ }^{1}$

${ }^{1}$ UMR CNRS 6554 LETG-Angers, UFR Sciences, University of Angers, Angers, France

${ }^{2}$ World Wildlife Fund, Washington, DC, USA

${ }^{3}$ Sustainability Research Unit, Nelson Mandela University, South Africa

${ }^{4}$ Instituto de Biociências, Universidade Federal de Mato Grosso do Sul, Campo Grande, MS,

Brazil

${ }^{5}$ Centre for Tropical Environmental and Sustainability Science (TESS) and College of Science and Engineering, James Cook University, Cairns, QLD 4878, Australia

${ }^{6}$ LTSER France, CNRS, Hwange National Park, Bag 62, Dete, Zimbabwe

${ }^{7}$ ESO, UMR CNRS 6590, University of Le Mans, France

${ }^{8}$ UCBL, UMR CNRS 5558, University of Lyon, France

*Corresponding author: Email: julien.blanco.pro@gmail.com Phone: +3367879011 10

Keywords: biodiversity conservation; buffer zones; natural resource governance; landscape change; protected area management; transition areas

Paper type: Research review 


\begin{abstract}
Land use changes and the expansion of protected areas (PAs) have amplified the interaction between protected and unprotected areas worldwide. In this context, 'interface processes' (human-nature and cross-boundary interactions inside and around PAs) have become central to issues around the conservation of biodiversity and ecosystem services. This scientific literature review aimed to explore current knowledge and research gaps on interface processes regarding terrestrial PAs. First, 3,515 references related to the topic were extracted through a standardized search on the Web of Science and analyzed with scientometric techniques. Next, a full-text analysis was conducted on a sample of 240 research papers. A keyword analysis revealed a wide diversity of research topics, from 'pure' ecology to socio-political research. We found a bias in the geographical distribution of research, with half the papers focusing on eight countries. Additionally, we found that the spatial extent of cross-boundary interactions was rarely assessed, preventing any clear delimitation of PA interactive zones. In the 240 research papers we scanned, we identified 403 processes that had been studied. The ecological effects of PAs were well documented and appeared to be positive overall. In contrast, the effects of PAs on local communities were understudied and, according to the literature focusing on these, were very variable according to local contexts. Our findings highlight key research advances on interface processes, especially regarding the ecological outcomes of PAs, the influence of human activities on biodiversity, and PA governance issues. In contrast, main knowledge gaps concern the spatial extent of interactive zones, as well as the interactions between local people and conservation actions and how to promote synergies between them. While the review was limited to terrestrial PAs, its findings allow us to propose research priorities for tackling environmental and socio-economic challenges in the face of a rapidly changing world.
\end{abstract}




\section{Introduction}

Worldwide, land use changes driven by the expansion of human activity and infrastructure on the one hand, and by initiatives to protect terrestrial biodiversity on the other, have created landscapes with increasing interaction between humans and biodiversity. Indeed, humandominated areas - including rangelands, managed forests, and cultivated lands - now occupy around $80 \%$ of the planet (Haddad et al., 2015; Ramankutty et al., 2018). Their expansion has vastly increased the extent of fragmented landscapes where a wide range of interactions take place between natural and human-modified habitats (Driscoll, Banks, Barton, Lindenmayer, \& Smith, 2013). In parallel, statutory terrestrial protected areas (PAs) have been expanding and now cover around 15\% of the planet (UNEP-WCMC \& IUCN, 2016), multiplying contact zones and interactions between protected and unprotected areas (Watson, Dudley, Segan, \& Hockings, 2014). As many PAs are actively managed, and sometimes inhabited, by humans (categories IV-VI of the IUCN; Shafer, 2015), a vast range of human-biodiversity interactions occur within their boundaries.

In this context, the role of 'interface processes' has become central to questions regarding the conservation of ecosystems and biodiversity in protected and unprotected areas and, consequently, of ecosystem services (Cumming, 2016; DeFries et al., 2010; Hansen \& DeFries, 2007; Mathevet, Thompson, Folke \& Stuart Chapin, 2016; Palomo et al., 2014). In this paper, interface processes are defined based on two main types of interactions that occur in terrestrial PA-related social-ecological systems (SES; Fig. 1):

- Local social-ecological interactions: These are interactions between human and nonhuman components (i.e. at the interface between social and ecological systems) that occur either outside or inside PAs. One aspect of these interactions refers to the influence of humans on their local environment, through road expansion that alters species distribution and landscapes (Spellerberg, 1998), agricultural practices that influence biodiversity at field and landscape scales (Carrié, Andrieu, Ouin, \& Steffan-Dewenter, 2017), or PA management practices that aim to conserve or restore ecological assets (ChamailléJammes, Charbonnel, Dray, Madzikanda, \& Fritz, 2016). The other aspect refers to the influence of biodiversity on humans, through the various ecosystem services humans derive from ecosystem production and functioning (Bennett et al., 2015) or the negative impacts - what can be termed ecosystem disservices (Shackleton et al., 2016).

- Cross-boundary interactions: These are biophysical, social and social-ecological interactions between areas predominantly managed for biodiversity conservation and areas predominantly managed for human activities. In contrast to local social-ecological interactions, cross-boundary interactions are specific to PA-related SES, and refer to the many influences of PAs on their surroundings (and vice versa); these are variously termed 'spillover effects', 'edge effects', or 'boundary effects' in the literature (Ament \& Cumming, 2016; Balme, Slotow, \& Hunter, 2010). For example, animal movements into and out of PAs to feed or migrate (Loveridge, Valeix, Elliot, \& Macdonald, 2017) generate biophysical cross-boundary interactions. When these animals enter adjacent agro-pastoral areas or human settlements, this creates social-ecological interactions (e.g. crop raiding, retaliation killings) that may affect wildlife survival as well as human societies (Guerbois, Chapanda, \& Fritz, 2012). Finally, these phenomena sometimes lead to negative attitudes of adjacent communities toward PAs, which may in turn affect their social interactions with PA managers (Castilho, De Vleeschouwer, Milner-Gulland, \& Schiavetti, 2018; Chouksey \& Singh, 2018). 


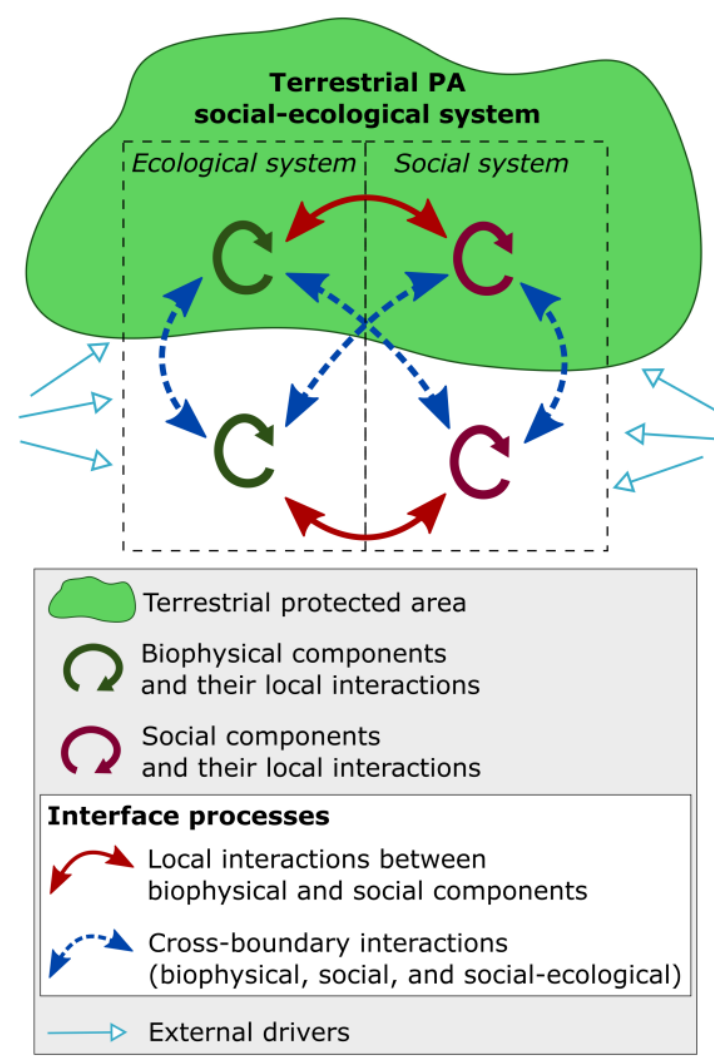

Fig. 1 Conceptual diagram of the two types of interface processes within PAs and across their boundaries. The first type (red plain lines) refers to local social-ecological interactions between human and non-human components (either inside PAs or in their surroundings). The second type (blue dotted lines) refers to cross-boundary interactions between biophysical, social, and social-ecological components.

Altogether, interface processes substantially influence interactions between social and ecological components (i.e. a species, a stakeholder, etc.) within a PA-related SES (Fig. 1). A clear understanding of interface processes and their effects on biodiversity inside and outside of PAs as well as on social systems is crucial in order to improve PA management and biodiversity conservation. In a context of shifting climatic conditions, biodiversity conservation in the near future will rely on the ability of species to move outside current PA networks, which will be facilitated by effective biodiversity-friendly actions in unprotected areas (Lehikoinen, Santangeli, Jaatinen, Rajasärkkä, \& Lehikoinen, 2019). Yet if these actions deprive local communities of the natural resources important to their livelihoods, they may jeopardize community well-being and undermine social support for conservation (McElwee, 2010). A better understanding of local social-ecological interactions will help to avoid this pitfall. Secondly, providing information on the effect of cross-boundary interactions on biodiversity inside PAs will help PA managers to adapt their management plans and actions. As advocated by many studies, such adaptations may include involving adjacent communities and stakeholders in PA co-management (Agrawal \& Ostrom, 2006; Porter-Bolland et al., 2012; Thoms, 2008).

A large body of knowledge exists on interface processes. The aim of this review was to provide a thorough and critical analysis of the peer-reviewed literature focusing on terrestrial PAs. To this end, we first conducted a quantitative review of the literature to shed light on the main research topics that relate to interface processes. We then summarized the current knowledge of these processes through a full-text analysis of a selection of papers, emphasizing empirical results and advances. Lastly, we identified key gaps in the research. 
Our findings indicate the need for integrated research that will help to better understand the complex links between land use, socio-economic change, cultural change and biodiversity, which represent a critical challenge for fostering biodiversity conservation and local development in the Anthropocene.

\section{Materials \& methods}

\section{Systematic review and bibliometric analyses}

The first step of the review was to search the Web of Science's Core Collection for literature on interface processes associated with PAs over the past 30 years (1988-2018), limiting our scope to terrestrial PAs (i.e. marine and urban PAs were excluded). To conduct the search, we designed standardized queries using keywords referring to PAs (e.g. 'conservation area*', 'protected area*', 'national park*', etc.) that co-occurred with keywords referring either to PA surroundings (e.g. 'buffer zone*', 'buffer area*', 'around', 'adjacent', etc.) or to interactions between human and social systems (e.g. 'interface*', 'social-ecological', etc.) (see Table S1 for further details). These queries led to a corpus of 3,515 references on interface processes associated with terrestrial PAs, part of a larger corpus of 41,710 references on terrestrial PAs more generally (Table S1). According to the terms used by the authors to designate PA surroundings or the interactions between ecological and social systems, we classified each reference into one of six categories, including 'buffer area', 'buffer zone', 'interface', 'proximity adjectives', 'social-ecological', and 'multiple' (Table 1).

Table 1. Description of the six categories used to classify the 3,515 papers collected in the search, including the classification criteria, the number of papers, and examples in each category.

\begin{tabular}{|c|c|c|c|}
\hline Categories & $\begin{array}{c}\text { Classification criteria } \\
\text { (based on the use of each notion in the title, } \\
\text { abstract or keywords) }\end{array}$ & $\begin{array}{l}\text { No. of } \\
\text { papers }\end{array}$ & Examples of references \\
\hline Buffer area & $\begin{array}{l}\text { Use of the concept of 'buffer area' to designate } \\
\text { PA surroundings (and none of the other } \\
\text { concepts in our classification) }\end{array}$ & 24 & $\begin{array}{l}\text { (Kinnaird et al., 2003; Román-Cuesta } \\
\text { \& Martínez-Vilalta, 2006) }\end{array}$ \\
\hline $\begin{array}{l}\text { Buffer } \\
\text { zone }\end{array}$ & $\begin{array}{l}\text { Use of the concept of 'buffer zone' to designate } \\
\text { PA surroundings (and none of the other } \\
\text { concepts in our classification) }\end{array}$ & 412 & $\begin{array}{l}\text { (Fernández-Juricic, Vaca, \& } \\
\text { Schroeder, 2004; Hoa Hong Dao \& } \\
\text { Hölscher, 2015) }\end{array}$ \\
\hline Interface & $\begin{array}{l}\text { Use of the concept of 'interface' to designate } \\
\text { interactions between biodiversity and societies, } \\
\text { or between PA and their surroundings (and } \\
\text { none of the other concepts in our classification) }\end{array}$ & 224 & $\begin{array}{l}\text { (Chapple et al., 2011; Magige \& } \\
\text { Senzota, 2006) }\end{array}$ \\
\hline $\begin{array}{l}\text { Proximity } \\
\text { adjectives }\end{array}$ & $\begin{array}{l}\text { Use of proximity adjectives to designate PA } \\
\text { surroundings, including 'around', 'edge', } \\
\text { 'adjacent', 'near', 'surrounding*', 'border*', } \\
\text { 'periphery', 'boundary', and 'adjoining' (and } \\
\text { none of the other concepts in our classification) }\end{array}$ & 2278 & $\begin{array}{l}\text { (Fernández \& Gómez, 2012; William } \\
\text { D. Newmark et al., 1996) }\end{array}$ \\
\hline $\begin{array}{l}\text { Social- } \\
\text { ecological } \\
(\text { SES) }\end{array}$ & $\begin{array}{l}\text { Use of the concepts of 'social-ecological', } \\
\text { 'socio-ecological' or 'socio-ecosystem' to } \\
\text { designate interactions between biodiversity and } \\
\text { societies in or around PA (and none of the other } \\
\text { concepts in our classification) }\end{array}$ & 346 & $\begin{array}{l}\text { (Pinki Mondal \& Southworth, 2010; } \\
\text { Murungweni et al., 2011) }\end{array}$ \\
\hline Multiple & $\begin{array}{l}\text { Use of at least two of the above-mentioned } \\
\text { concepts to designate PA surroundings or the } \\
\text { interactions between biodiversity and societies }\end{array}$ & 231 & $\begin{array}{l}\text { (Haggar et al., 2015; Kintz, Young, \& } \\
\text { Crews-Meyer, 2006) }\end{array}$ \\
\hline Total & & 3515 & \\
\hline
\end{tabular}


We then identified the main journals and the timeline of appearance of the different terms, and analyzed (i) the countries/territories of affiliation of the authors and (ii) the keyword cooccurrence patterns. For the latter, we created a distance-based map of keywords with a bibliometric mapping software (i.e. VOSviewer 1.6.9, van Eck \& Waltman, 2010). The map reflects the association strength ' $s$ ' between keywords, calculated with the following direct similarity measure:

$$
s=\frac{\mathrm{c}_{i j}}{\mathrm{~s}_{i} s_{j}}
$$

where $c_{i j}$ equals the number of co-occurrences of keywords $i$ and $j$, and $s_{i}$ and $s_{j}$ equal the total number of occurrences of keywords $i$ and $j$, respectively. On the basis of this map, we identified clusters of keywords through a modularity-based clustering method based on minimizing Eq.(3) in Waltman, van Eck, \& Noyons (2010), which is a widely used clustering method in scientometric research.

\section{Full-text analysis of a sub-corpus of articles}

A full-text analysis was then carried out on a sub-corpus of articles in order to extract information from their 'Methods' and 'Results' sections. To select this sub-corpus, we followed the standardized procedure described in Fig. 2. From the full complement of 3,515 references, we first selected a sub-corpus of 1,199 papers published in the 19 most represented journals (i.e. journals that have included at least one article per year on interface processes over the last 30 years). From this sub-corpus, we randomly selected 335 papers (ca. $10 \%$ of the complete corpus). A full-text analysis of these papers allowed us to identify the 240 empirical research articles that were most relevant to our analysis, i.e. studies that focused on terrestrial PAs and analyzed one or many biophysical, social and/or social-ecological components or interactions (excluding gap analyses, method articles and concept and opinion papers).

The full-text analysis of the 240 research articles was carried out in order to systematically extract the following information:

- the country(ies)/territory(ies) where the study was conducted

- the existence or not of a formally legislated management zone (i.e. buffer zone and/or transition area)

- the definition of the zone that interacts with the PA, if included in the paper

- the nature of the studied component(s) or interaction(s), grouped into 25 different types and 11 larger categories (see Table S2)

- where relevant, the nature of the interaction (either positive, negative or neutral) between the studied components

- the nature of the data used in the study (i.e. social, biophysical or both)

- the methods used to collect or handle the data

- the location of the data collection site (inside PAs, in PA surroundings, or both).

This analysis was performed by the first two authors, who designed the analytical grid together and regularly discussed how to code an article or a variable in order to reduce bias. In addition, the studied components and interactions were grouped into different types, and subsequently into broader categories, in order to homogenize the dataset and uncover dominant trends and effects for similar types of components and interactions. This resulted in the classification system presented in Table S2, which was established through a bottom-up approach: after the identification of 403 studied components and interactions from the fulltext analysis of the 240 research articles, the first two authors agreed to group them into 25 different types, which were then grouped into 11 larger categories. 


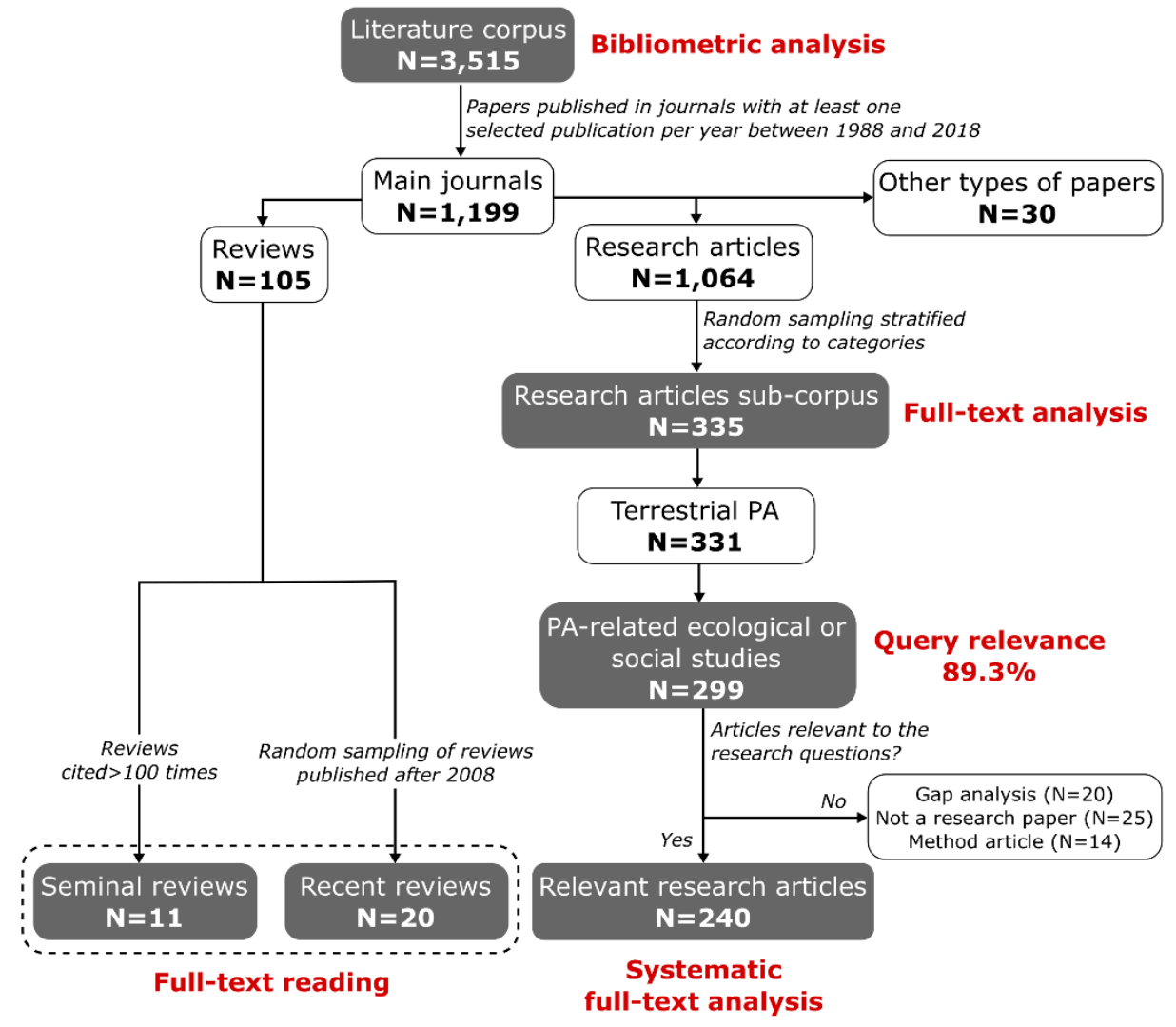

Fig. 2 Selection procedure of the 240 research articles and 31 reviews used for the full-text analysis of the literature. This procedure also allowed the assessment of the rate of relevancy of the query, i.e. its capacity to capture existing studies of interface processes in the context of terrestrial protected areas.

To complete the analysis, 31 reviews were selected, including 11 seminal reviews (i.e. reviews cited >100 times) and 20 recent reviews (published after 2008) (Fig. 2). These reviews were analyzed with the aim of shedding light on key research advances, salient results and seminal publications in the field. They allowed us to enrich our understanding and to gain a broader perspective on the state of the art in interface processes.

For the sake of clarity, hereafter we will use the term 'studied process' to designate the components and interactions that were identified in the scanned full texts. Components refer to a social or an ecological entity (i.e. a stakeholder, a social norm, a species, a habitat, etc.) or to the variables used to describe an entity (i.e. the social status of a stakeholder, the level of diversity of a habitat, etc.). The term 'interaction' refers to the relationships between entities and how they influence each other. Of the 'studied processes', interface processes designate more specifically cross-boundary interactions or human-biodiversity interactions, as defined in the introduction. The zone that interacts (or is supposed to interact) with PAs though crossboundary interactions is referred as the 'interactive zone'.

\section{Results}

\section{Geographical imbalances}

The literature on interface processes represented $8.4 \%(N=3,515$ references $)$ of the total literature extracted on PAs $(N=41,710$; Table S1). A total of 10,403 authors associated with 140 countries/territories contributed to this literature on interface processes, of whom 29 contributed to eight or more papers. Most papers were published by authors from the United States $(N=1,184 ; 33.7 \%)$, the United Kingdom $(N=364 ; 10.4 \%)$, South Africa $(N=270 ; 7.7 \%)$ 
and Canada ( $N=248 ; 7.1 \%$ ) (Fig. 3a). Beyond the dominance of authors from North America $(N=1,333$ papers; $37.9 \%)$ and Europe $(N=1,367 ; 38.9 \%)$, several other countries were disproportionately represented, including South Africa, China $(N=142 ; 4.0 \%)$, India $(N=125$; $3.6 \%)$ and Brazil $(N=124 ; 3.5 \%)$. North and West Africa and the Middle East $(N=28 ; 0.8 \%)$ were underrepresented.

\section{(a) Number of papers according to authors' country of affiliation}

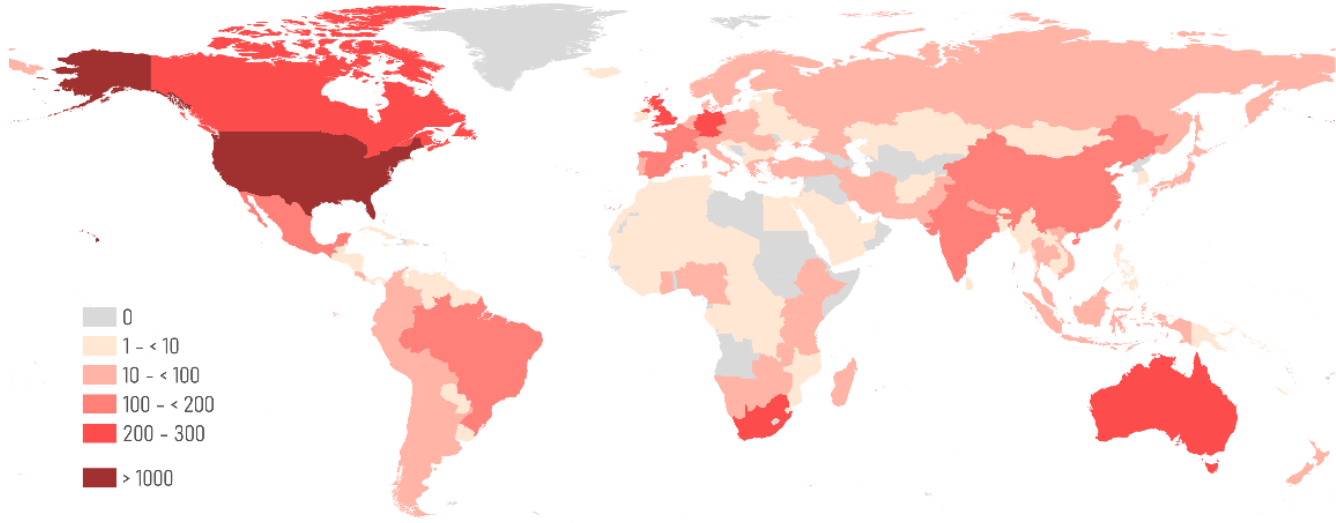

(b) Number of papers according to the study site location and co-authorship links

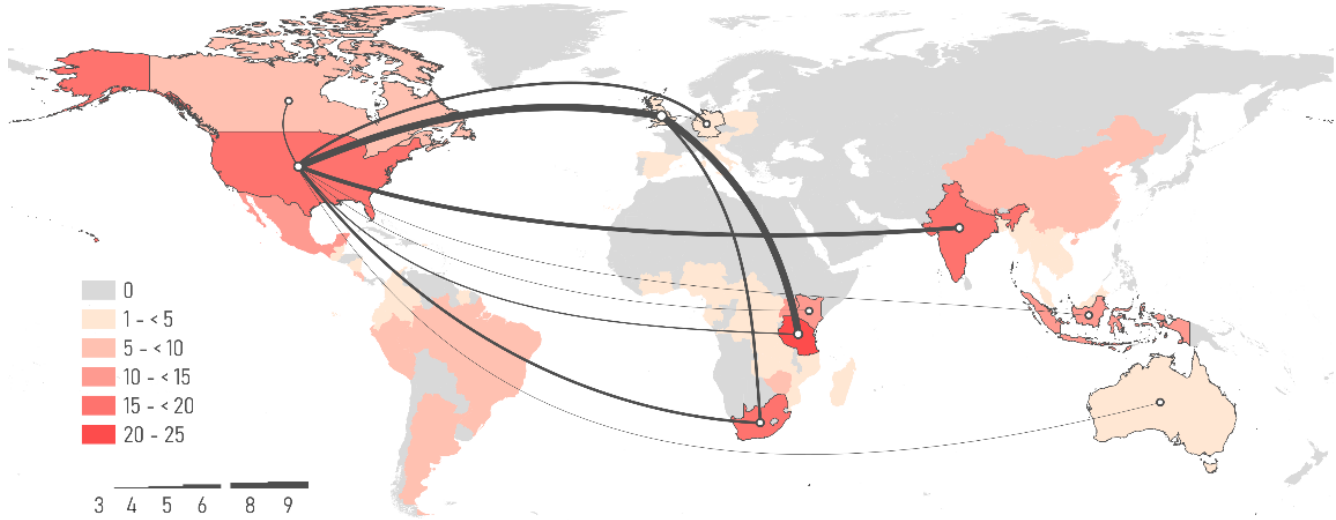

(c) Protected area coverage per country/territory

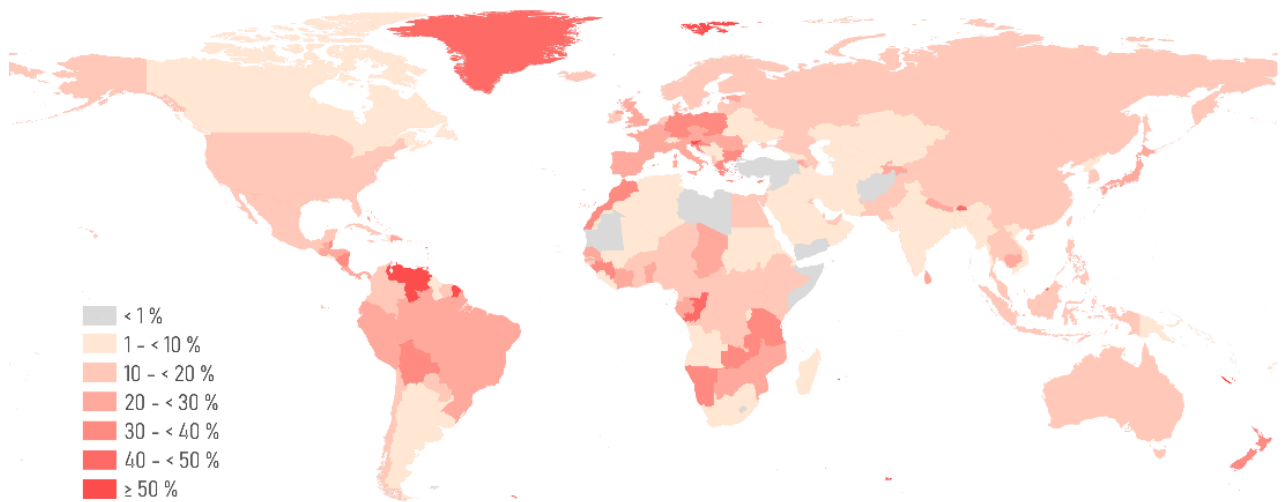

Fig. 3 Geographical distribution of authors and study sites of the selected literature, and terrestrial PA coverage. (a) Number of papers published for each country/territory on the basis of author affiliation (based on the full complement of 3,515 references); (b) Number of papers published on each country/territory on the basis of the location of study sites, and co-authorship links between countries/territories (based on the scanned 240 articles); (c) Proportion of land covered by protected area for each country/territory (Source: UNEP-WCMC \& IUCN, 2018). 
In the 240 research articles we scanned, study sites were located in 85 different countries (Fig. 3b), but 8 countries were the focus of $>50 \%$ of the articles: Tanzania $(N=23 ; 9.6 \%)$, India $(N=20 ; 8.3 \%)$, USA $(N=18 ; 7.5 \%)$, South Africa $(N=16 ; 6.7 \%)$, Nepal $(N=15 ; 6.3 \%)$, Indonesia $(N=11 ; 4.6 \%)$, Kenya $(N=11 ; 4.6 \%)$ and Uganda $(N=11 ; 4.6 \%)$. Overall, $75 \%$ of the articles focused on 15 countries, with 35 countries appearing in just one article. Co-authorship links indicated the strong involvement of authors based in Europe and North America in articles dealing with study sites located in developing countries (Fig. 3b). Thus, developing and emergent countries were overrepresented as study sites, while developed countries were overrepresented in terms of authors. Large geographical areas remained overlooked, in particular North Africa, the Middle East and Central Asia, which may be partly explained by the relatively low occurrence of statutory PAs in these regions (Fig. 3c).

\section{Research at the crossroads between social and ecological sciences}

Between 1988 and 2018, the number of annual publications on terrestrial PA-related interface processes rapidly increased (Fig. 4a). With 199 papers, Biological Conservation was the main publishing journal, followed by Conservation Biology (98 papers) and ORYX (95, Fig. 4b). Thus, interface processes have tended to be investigated mainly through the lens of biodiversity conservation. This result was corroborated by the two most frequent keywords: 'conservation' (in 287 papers; 8.2\%) and 'biodiversity' (107 papers; 3.0\%).

Through the analysis of keyword co-occurrences, we identified 70 frequent keywords (appearing in 20 or more papers) pointing to a wide diversity of research topics, approaches and methods (Fig. 5). Within these, five main clusters, related to five core topics, emerged:

- Species diversity and distribution across landscapes: This cluster is dominated by keywords referring to biodiversity surveys (e.g. 'species richness', 'camera trap') and to species' use of their habitats (e.g. 'distribution', 'home range', 'predation') in the context of human-modified landscapes, as suggested by the keywords 'buffer zone', 'land use' and 'edge effects'.

- Landscape changes and their impacts on biodiversity: This cluster is dominated by keywords referring to landscape ecology (e.g. 'remote sensing', 'fragmentation', 'connectivity') in the context of changes in land use and cover as well as in climate.

- Interactions between local people and protected areas: This cluster is dominated by keywords illustrating the impact of wildlife on local people (e.g. 'human-wildlife conflict', 'crop raiding') and by keywords highlighting the benefits PAs provide to people (e.g. 'ecotourism') in the context of PA co-management.

- Governance of protected areas: This cluster is characterized by social-ecological approaches and associated keywords (e.g. 'ecosystem services', 'resilience', 'institutions') in the context of sustainable and participative management of PAs.

- Wildlife conservation and anthropogenic threats: This cluster is dominated by population ecology keywords (e.g. 'population dynamics', 'habitat selection') in the context of anthropogenic pressures on wildlife through hunting and poaching.

These five topics reflect the diversity of approaches employed to address conservation issues, including wildlife-centered, social-centered and landscape ecology approaches. As illustrated by the keywords referring to the impacts of conservation on local populations and to PA governance and management challenges, the synergies and antagonisms between human development and biodiversity conservation appear as major research themes. Yet the position of, and links between, the different keywords, suggest strong overlaps between clusters (Fig. 5). Rather than disconnected research topics, the keyword map highlights a gradient 
between 'pure' ecological research (left side of Fig. 5) and social-ecological research (right side).
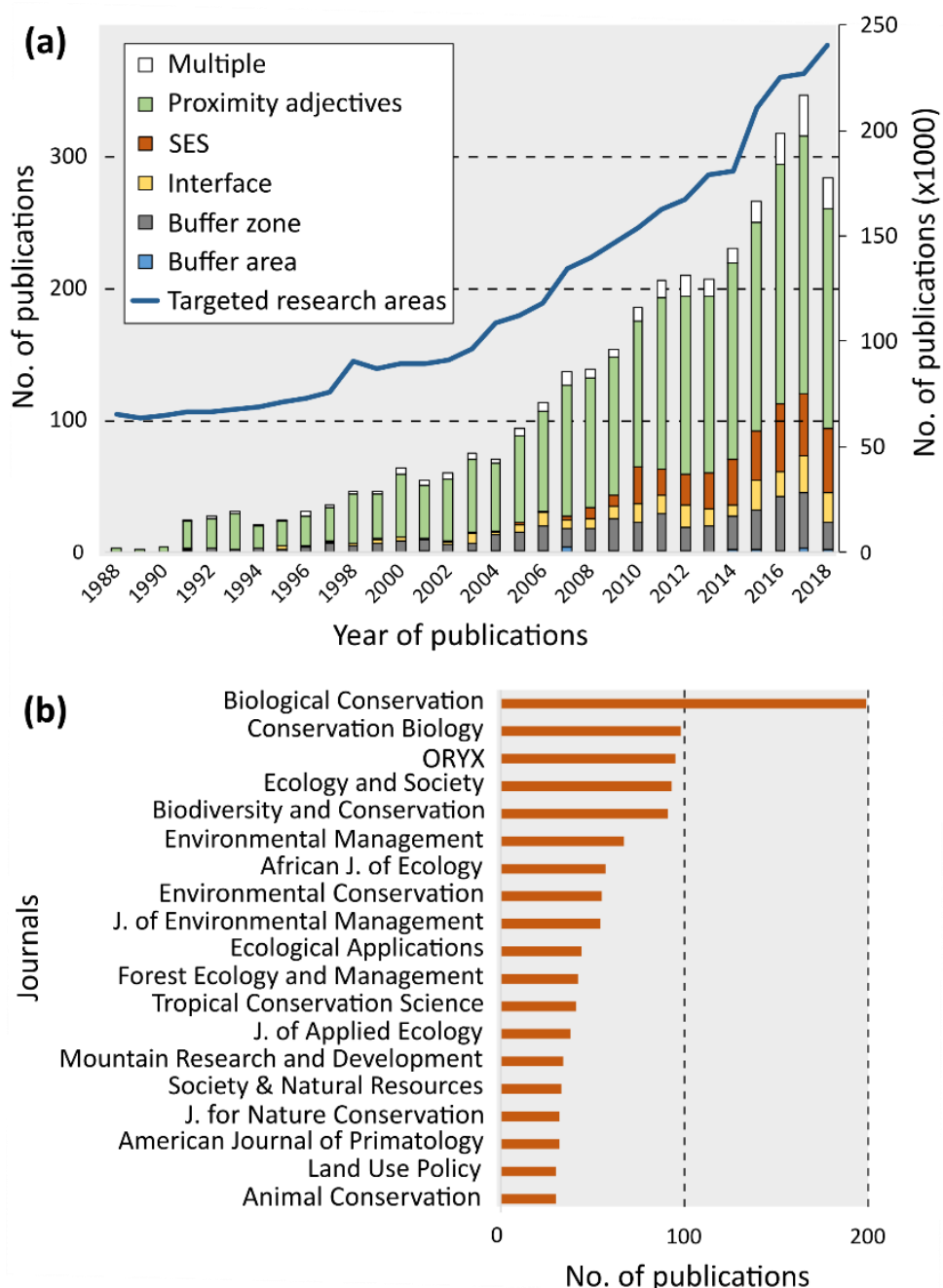

Fig. 4 Annual publications on terrestrial PA-related interface processes and main publishing journals. (a) Annual publications since 1988 according to the term used to designate interface processes and/or PA surroundings, and comparison with the annual publication of the targeted research areas (i.e. the Web Of Science research areas included in this review: 'Environmental Sciences Ecology'; 'Zoology'; 'Biodiversity conservation'; 'Plant Sciences'; 'Forestry'; 'Agriculture'; 'Geography'; 'Social Sciences Other topics'). (b) Number of publications in the 19 journals that have published at least one paper per year on interface processes since 1988. 


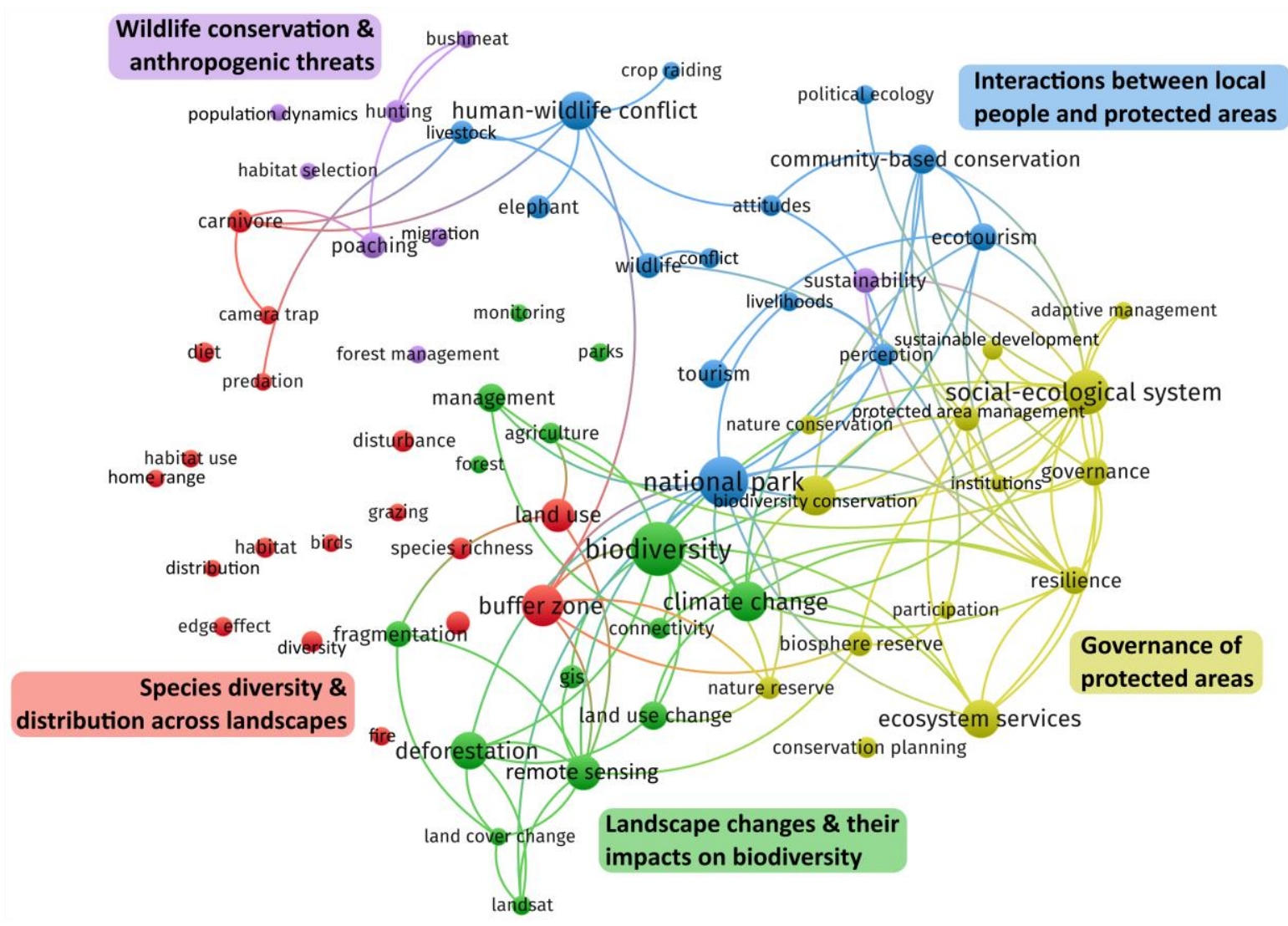

Fig. 5 Distance-based map of the main keywords and their association strength in the selected literature, depicting five core research topics identified by a modularity-based clustering method. This figure highlights the 69 keywords ('conservation' excluded) appearing in at least 20 articles and their co-occurrence links extracted from the 3,515 references. Circle sizes are proportional to the occurrence of each keyword. Co-occurrence links indicate keywords that appear together in at least three papers, and the thickness of the line is proportional to the number of co-occurrences of keywords. Colors correspond to the five clusters obtained with the modularity-based clustering method (implemented in VOSviewer software).

\section{The unclear characterization of interactive zones}

We found a lack of clarity in the way the zones that interact with PAs (i.e. 'interactive zones') were described and defined in the selected research articles. Firstly, the coexistence of a diversity of terms to refer to interactive zones and cross-boundary interactions suggested a lack of uniform denomination (Fig. 4a). The majority of papers used proximity adjectives $(N=2,278 ; 64.8 \%)$ such as 'around', 'adjacent' or 'near' (Table 1$)$. The most noticeable change in designation was the emergence of the concept of 'social-ecological system' (SES) in 1991, which became a frequent way to refer to PA-related interface processes.

Secondly, interactive zones were defined in only 21 of the 240 research articles we scanned, and these definitions revealed contrasting visions (Table S3). These mostly referred to 'buffer zones' $(N=20)$, understood as areas of trade-offs between local livelihoods and biodiversity conservation. More specifically, 8 definitions emphasized the restrictions imposed on human activities, while 9 emphasized the allowance of sustainable activities. An alternative vision of the buffer zone and its functions (found in one paper) considered it as a sacrificed area "meant to protect its conservation unit from deforestation rather than itself, to reduce edge effects, to protect from gold mining, drug cultivation, poaching and maintaining viable population of species" (Jusys, 2016). 
Beyond terminology and conceptual considerations, 52 research papers $(21.7 \%$ of the 240 references) did not integrate PA surroundings in their study design, referring to them only in the introduction or discussion. For the remaining 188 papers, the spatial boundaries of the zone investigated were mainly established from pre-existing institutional, administrative or legislated boundaries rather than biophysical or cultural boundaries such as watersheds or traditional land tenure (Fig. 6). Arbitrary and technology-driven delineations were common (e.g. an arbitrary distance from the PA boundary without justification of the definition of the particular distance used, or boundaries based on the availability of aerial photographs), while 33 articles did not explicitly delimit the zone they investigated. Only 12 papers considered biophysical and/or cultural criteria to determine boundaries.

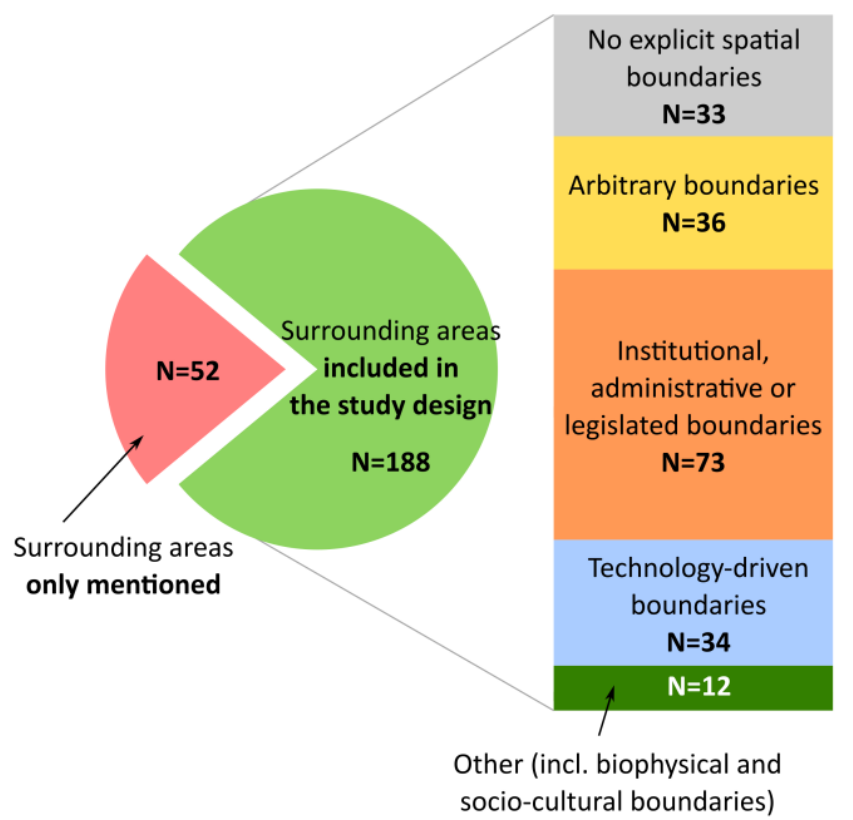

Fig. 6 Studies mentioning or considering the surrounding areas of PAs, and approaches to defining their boundaries. The pie chart shows the number of papers that only mention PA surroundings (in the introduction or discussion) and the number of papers that included them in their study design. Of these, the bar chart indicates the way the zones of interest were designated in the papers.

\section{A lack of consideration of cross-boundary interactions}

From the 240 research articles, we identified a total of 403 studied processes (components and/or interactions). Most investigated processes $(n=242 ; 60.0 \%)$ did not consider crossboundary interactions (Fig. 7). Of these, 78 processes (19.4\%) were studied only inside PAs, merely incorporating the effect of cross-boundary interactions to contextualize or discuss results (e.g. Gurd, Nudds, \& Rivard, 2001; Newmark, Boshe, Sariko, \& Makumbule, 1996). For 91 studied processes $(22.6 \%)$, the area around PAs was used as a control to test the effect of PAs on a given ecological process such as species communities (e.g. Fernández \& Gómez, 2012) or land cover changes (e.g. Mondal \& Southworth, 2010). Finally, 73 processes $(18.1 \%)$ were assessed independently of PA boundaries, which included studies about genetic variation in animal populations (e.g. Forbes \& Boyd, 1996), livelihoods (e.g. Murungweni, van Wijk, Andersson, Smaling, \& Giller, 2011), or land use changes in unprotected areas (e.g. Brandt, Allendorf, Radeloff, \& Brooks, 2017). 


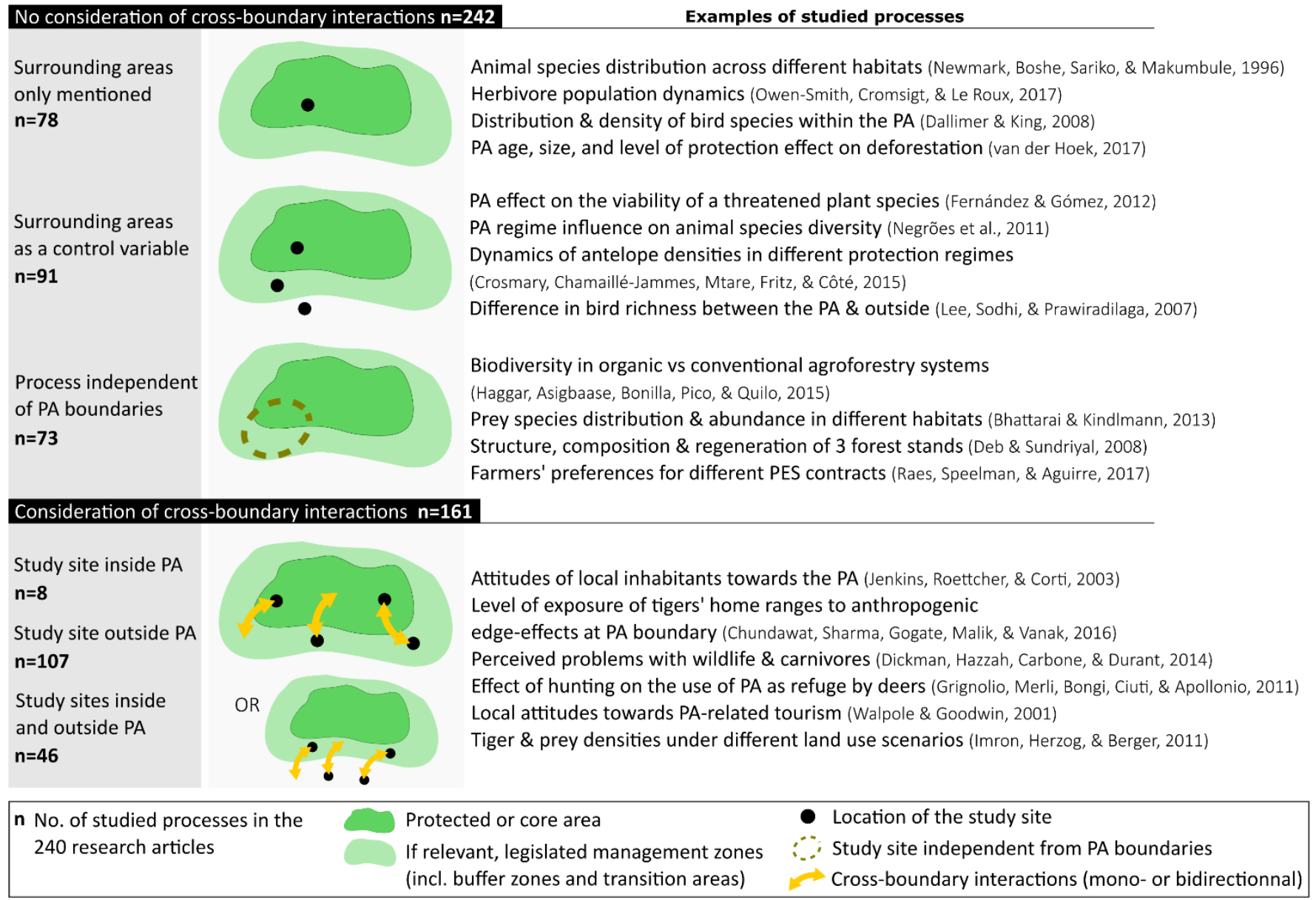

Fig. 7 Consideration of cross-boundary interactions in the literature and examples of studied processes. Each studied process identified in the 240 research articles was classified according to (i) the location of the study site and (ii) whether the study integrated the influence of crossboundary interactions. Black dots show study sites, which may be located inside the PA, in a legal management zone, or outside the PA. Arrows indicate whether cross-boundary interactions were considered to influence the studied process.

When cross-boundary interactions were considered $(n=161 ; 40.0 \%)$, study sites were predominantly located outside PAs $(n=107 ; 26.6 \%)$, and very few $(n=46 ; 11.4 \%)$ combined locations inside and outside a PA. Seventy-two (17.9\%) cross-boundary interactions were associated with the influence of PAs on their surroundings: on neighboring people's attitudes toward conservation (e.g. Lagendijk \& Gusset, 2008), on human-wildlife conflicts (e.g. Seiler \& Robbins, 2016), or on development outcomes (e.g. Baird, 2014). Conversely, 69 (17.1\%) cross-boundary interactions concerned the influence of surrounding areas on PAs, such as hunting pressure (Altrichter, 2005) or natural resource extraction (e.g. Shova \& Hubacek, 2011). Only 29 cross-boundary interactions (7.2\%) were considered as two-way relationships between PAs and interactive zones, which included the study of animal movements between PAs and neighboring lands (e.g. Balme, Slotow, \& Hunter, 2010), the involvement of local people in PA governance (e.g. Nepal, 2002), or social relationships between stakeholders (e.g. Zhou, Wang, Lassoie, Wang, \& Sun, 2014).

\section{Overview of the methods and research topics}

The 240 research articles were dominated by biophysical studies $(N=127 ; 53.0 \%)$ that used a diverse set of methods, including ecological surveys, remote sensing and modeling approaches (Fig. 8a,b). A total of 76 articles (31.7\%) used only social data collected through 
field interviews conducted by the authors (including questionnaires) or through the use of other types of social surveys such as preexisting socio-economic censuses, poaching records obtained from local patrollers, tourism records, or expert-based information. Articles combining biophysical and social data were fewer $(N=37 ; 15.3 \%)$. Nearly one-third of the articles $(N=71 ; 29.6 \%)$ combined different methods (such as ecological surveys and remote sensing, or ecological surveys and field interviews) (Fig. 8b).

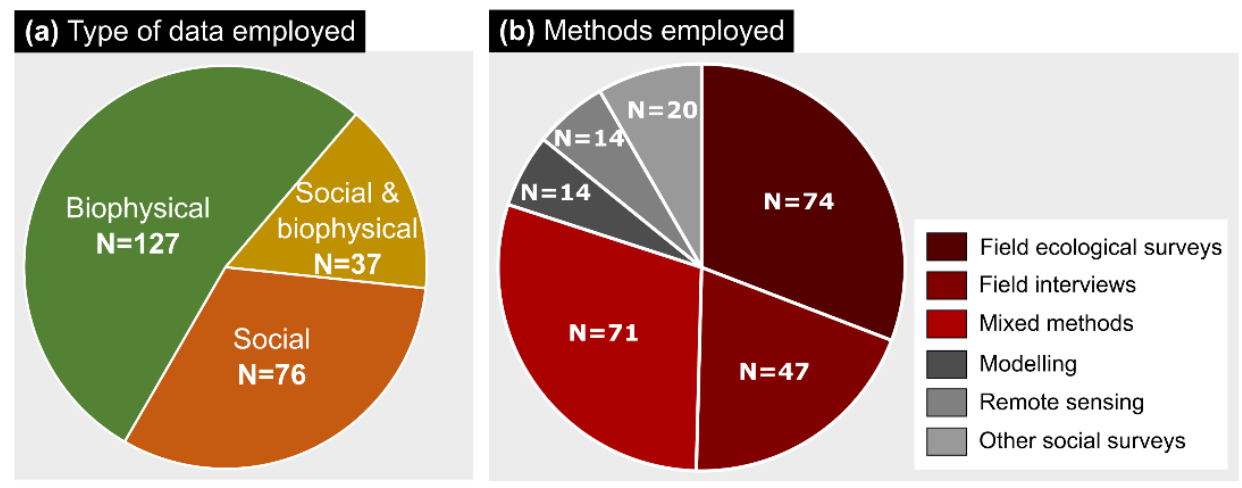

(c) Categories of studied processes and dominant trends according to study site location

\begin{tabular}{|c|c|c|c|c|c|}
\hline \multicolumn{2}{|c|}{ Studied processes } & $\begin{array}{l}\text { Inside } \\
\text { PAs }\end{array}$ & $\begin{array}{l}\text { Outside } \\
\text { PAs }\end{array}$ & $\begin{array}{l}\text { Inside \& } \\
\text { Outside }\end{array}$ & All \\
\hline \multicolumn{2}{|c|}{ Biophysical components $\&$ their interactions } & 24 & 35 & 53 & 112 \\
\hline \multicolumn{2}{|c|}{ Biodiversity \& its distribution across landscapes } & 19 & 29 & 42 & 90 \\
\hline \multicolumn{2}{|c|}{ Landscape \& habitat characteristics \& dynamics } & 5 & 5 & 9 & 19 \\
\hline \multicolumn{2}{|c|}{ Ecosystem service assessments } & 0 & 1 & 2 & 3 \\
\hline \multicolumn{2}{|l|}{ Interface processes } & 52 & 76 & 141 & 269 \\
\hline \multicolumn{2}{|c|}{ Local human activities \& livelihoods } & 11 & 5 & 18 & 44 \\
\hline \multicolumn{2}{|c|}{ Human influence on biodiversity \& landscapes } & 13 & 23 & 35 & 71 \\
\hline \multicolumn{2}{|c|}{ Biodiversity influence on local activities \& livelihoods } & 3 & 8 & 8 & 19 \\
\hline \multicolumn{2}{|c|}{ Conservation effect on biodiversity } & $4+$ & $8 \sim$ & $29-$ & 40 \\
\hline \multicolumn{2}{|c|}{ Conservation effect on land use \& habitats } & 5 & 9 & $21 \simeq$ & 35 \\
\hline \multicolumn{2}{|c|}{ Conservation effect on local livelihoods \& development } & 4 & $3 \sim$ & 二 & $\sim$ \\
\hline \multicolumn{2}{|c|}{ Conservation governance $\&$ relationships with local people } & $12 \sim$ & $20 \simeq$ & $28 \sim$ & $61 \sim$ \\
\hline \multicolumn{2}{|l|}{ Other } & 4 & 3 & 5 & 12 \\
\hline \multicolumn{6}{|c|}{ Dominant trends \& effects (when relevant) } \\
\hline $\begin{array}{l}=\text { Neutral } \\
\sim \text { No dominant trend }\end{array}$ & $\begin{array}{l}\text { + Positive dominant trend in } n>50 \% \\
+ \text { Positive dominant trend in } 25<n<50 \%\end{array}$ & \multirow{2}{*}{\multicolumn{2}{|c|}{$\begin{array}{l}\text { - Negative domir } \\
- \text { Negative domir } \\
\text { ses (Total }=\mathbf{4 0 3} \text { ) }\end{array}$}} & $\begin{array}{l}\text { hant trend in } n \\
\text { ant trend in } 2\end{array}$ & $\begin{array}{l}>50 \% \\
5<n<50 \%\end{array}$ \\
\hline N: No. of papers (Tota & $\mathrm{n}$ : No. of studied pro & & & & \\
\hline
\end{tabular}

Fig. 8 Data and methods employed in the 240 research articles, and trends observed in the studied processes. (a) Number of papers according to the type of data (biophysical, social, or both) employed. (b) Number of papers according to the methods used in the analyses. (c) Number of times each studied process has been investigated according to study site location, and dominant reported trends when relevant (see Table S2 for further details on the types of processes).

The grouping of the 43 studied processes into 25 types and 11 categories (Table S2) allowed us to summarize the dominant trends and effects (Fig. 8c). A total of 112 (27.8\%) processes were related to ecological systems without consideration of interface processes, i.e. of socialecological or cross-boundary interactions. This literature was dominated by studies comparing species diversity and distribution across landscapes $(n=90 ; 22.3 \%)$, with a primary focus on animal species $(n=72 ; 17.9 \%)$ and less attention to plants $(n=18 ; 4.5 \%$; Table S2). This included research on species' habitat preferences (e.g. Bhattarai \& Kindlmann, 2013), variability in biodiversity between land use types (e.g. Haggar, Asigbaase, Bonilla, Pico, \& Quilo, 2015), or species abundance inside a PA at a single point in time (e.g. Dallimer \& 
King, 2008). Landscape and habitat analyses that, amongst other, aimed to characterize land cover and vegetation (e.g. Danby \& Slocombe, 2005) or rates of deforestation independently of the influence of PAs (e.g. Kinnaird, Sanderson, O'Brien, Wibisono, \& Woolmer, 2003) were less represented $(n=19 ; 4.7 \%)$. Studies that explicitly assessed ecosystem services were particularly scarce $(n=3)$.

Pure social system studies do not appear in Fig. 8c, as the papers selected by the search strings invariably investigated social interactions in the context of PAs or natural resource management, which we considered to be part of interface processes. Of the studied interface processes, three main topics emerged. The first was related to the interactions between biodiversity and local people, including studies of 'Local human activities \& livelihoods', 'Human influence on biodiversity \& landscapes', and 'Biodiversity influence on local activities \& livelihoods' (Fig. 8c). The second was related to the ecological effectiveness of conservation actions, including studies of 'Conservation influence on biodiversity' and 'Conservation influence on land use \& habitats'. The third topic focused on the social dimension of conservation actions, including studies of 'Conservation effects on local livelihoods \& development' and 'Conservation governance \& relationships with local people'.

\section{Interactions between biodiversity and local people}

Within this topic, studies on 'Local human activities \& livelihoods' ( $n=44 ; 10.9 \%)$ aimed to characterize the pattern of uses of biodiversity by local people and identify the underlying factors, focusing on the socio-economic factors involved in natural resource extraction (e.g. Shova \& Hubacek, 2011), on seasonal hunting patterns (e.g. Reyna-Hurtado, 2009), or on the link between wealth, education and natural resource dependence (e.g. Mgawe, Mulder, Caro, Martin, \& Kiffner, 2012). In a similar perspective, studies on 'Biodiversity influence on local activities \& livelihoods' ( $n=19 ; 4.7 \%)$ focused on non-material relationships between local people and biodiversity, such as local people's knowledge and attitudes toward wildlife (e.g. Dickman, Hazzah, Carbone, \& Durant, 2014; Nyhus, Sumianto, \& Tilson, 2003), as well as on material interactions such as human-wildlife conflicts, which were generally found to be exacerbated around PAs (e.g. Sarker \& Røskaft, 2010; Wegge, Yadav, \& Lamichhane, 2018; Woodroffe, Lindsey, Romañach, Stein, \& Ole Ranah, 2005).

Conversely, many studies aimed to assess 'Human influence on biodiversity \& landscapes' $(n=71 ; 17.6 \%)$, depicting an overall negative effect of human activities on biodiversity, both inside and outside PAs (Fig. 8c). The intensification of land use, the fragmentation of natural landscapes through the expansion of infrastructure, as well as logging and deforestation activities were found to be particularly detrimental to biodiversity (e.g. Armenteras, Rodríguez, \& Retana, 2009; Botha, Witkowski, \& Shackleton, 2004; Dallimer \& King, 2008; Thorn, Bässler, Svoboda, \& Müller, 2017). In contrast, the influence of agro-pastoral activities on biodiversity was found to be more variable according to the context and systems considered (e.g. Leigh, Smart, \& Gill, 2017; Mworia, Kinyamario, \& Githaiga, 2008; Petracca et al., 2014).

\section{The ecological effectiveness of conservation actions}

Most studies that focused on conservation areas' effects on biodiversity $(n=40 ; 9.9 \%)$ and land use and habitats $(n=35 ; 8.7 \%)$ found an overall positive effect at species and landscape levels (Fig. 8c). This included positive PA influences on pollinator communities (Fernández \& Gómez, 2012), on threatened tree species (Hoa Hong Dao \& Hölscher, 2015), and on forest conservation (Jusys, 2016). Yet PA effects on biodiversity were shown to be neutral in $26 \%$ of the cases, and negative in 13\% (Table S2). For example, Gurd et al. (2001) found that PAs 
in North America were generally too small to be effective in protecting mammal species, while Harihar, Pandav, \& Goyal (2011) warned about the negative influence of PAs on untargeted species due to interspecific competition.

\section{The social dimension of conservation actions}

Studies concerning the 'Conservation effect on local livelihoods \& development' were relatively scarce $(n=9 ; 2.2 \%)$ and had contrasting conclusions (Fig. 8c). While 'Conservation governance \& relationships with local people' featured strongly $(n=61 ; 15.1 \%)$, findings varied according to local contexts. For example, some studies reported that human-wildlife conflicts did not affect local people's support for conservation (e.g. Karanth, NaughtonTreves, Defries, \& Gopalaswamy, 2013; Lagendijk \& Gusset, 2008), while others concluded that it generated negative attitudes to conservation (e.g. Petracca et al., 2014; Stronen, Brook, Paquet, \& Mclachlan, 2007). Similarly, conflicts with PA staff were shown to contribute to negative attitudes to PAs (e.g. Newmark, Leonard, Sariko, \& Gamassa, 1993), although not everywhere (e.g. Studsrød \& Wegge, 1995). Further, while positive attitudes appeared to be favored when local people benefit from tourism or development (e.g. Archabald \& NaughtonTreves, 2001), people could also support PAs independently of these benefits (e.g. Walpole \& Goodwin, 2001).

\section{Discussion}

\section{Main advances in research on terrestrial PA interface processes}

A large number of scholars have highlighted that, far from being isolated islands, PAs are connected to human societies and to surrounding unprotected areas (e.g. Beale et al., 2013; Newmark, 2008), and are also generally part of a broader PA network (Gonzalez, Thompson, \& Loreau, 2017). As shown by publication trends, our results indicate that research on interface processes has increased exponentially over recent decades. This body of literature sheds light on both human-nature interactions inside and outside PAs, and the interactions between protected and unprotected areas.

A primary finding of our review was that studies confirm the overall positive effect of PAbased conservation strategies on biodiversity (Godet \& Devictor, 2018; Gray et al., 2016). The understanding researchers have gained on ecosystem functioning seems to have enabled the implementation of effective PA management strategies to maintain or improve this. However, our analysis also revealed that conservation measures and monitoring tend to focus on a limited number of vertebrate taxa (especially birds and mammals; Di Marco et al., 2017). To address this gap, future research should include other taxa such as plants and invertebrates, and develop multi-taxa approaches to expand the focus beyond emblematic or threatened taxa (Harihar et al., 2011). Further studies are also needed with regards to genetic and landscape level interactions (Aldana-Domínguez et al., 2017).

A second finding was that the literature on terrestrial PA-related interface processes has allowed robust conclusions to be reached about the influence of human societies on biodiversity and landscape dynamics. Consistent with the recent IBPES global assessment of biodiversity and ecosystem services (IPBES, 2019), the development of anthropogenic infrastructure, the intensification of land use and the unsustainable use of natural resources were found to be the main drivers of biodiversity loss inside and outside terrestrial PAs. A key challenge for fostering biodiversity conservation is therefore to reconcile human activities and ecosystem conservation. Research regarding the influence of agro-pastoral systems on biodiversity was underrepresented in the literature we reviewed (Table S2). Increasing 
research effort on this topic would enable the identification of farming and herding practices that could meet biodiversity conservation and food security challenges, as well as ways to move from lose-lose to win-win systems (Fischer et al., 2017).

Our review also partially assessed the vast literature on PA governance and the relationships between local communities and conservation stakeholders (Fig. 5, Fig. 8c). These studies provide insights on the main opportunities and pitfalls associated with the creation, implementation and management of terrestrial PAs (Adhikari \& Baral, 2018; Ellis \& PorterBolland, 2008; Zhou et al., 2014). Research questions included how to better engage local communities in PA management through community-based management, payment for ecosystem services, or by developing new economic opportunities through environmental certification or ecotourism. This body of knowledge may provide an important source of inspiration for PA managers. Yet our review was unable to extract clear answers to these questions (Fig. 8c), limiting our analysis (see the section 'Limits in the scope of this review' below).

\section{Critical research gaps and ways forward}

Despite a rapid increase in the number of studies on terrestrial PA-related interface processes, these still represent less than $10 \%$ of the total literature on PAs, and many research questions and challenges remain to be addressed. We identified three areas that we consider the most critical for future research.

The first knowledge gap relates to cross-boundary interactions and the definition and delineation of interactive zones. Evidence of this gap included the lack of clearly defined spatial boundaries of interactive zones in studies, but also the non-consensual views about their role (i.e. sacrificed zones vs. areas of trade-offs). Furthermore, a unidirectional understanding of cross-boundary interactions dominated, as few articles combined study sites both inside and outside PAs to investigate these interactions (but see Anderson \& O'Farrell, 2012; Balme et al., 2010). Several frameworks have been proposed to help (i) spatially delineate interactive zones, and (ii) consider two-way interactions between PAs and their surroundings, such as the 'Zone of Interaction' framework (DeFries, Karanth, \& Pareeth, 2010), the 'Ecological Solidarity' framework (Mathevet et al., 2016), or ecosystem servicebased frameworks (e.g. Palomo et al., 2014). Yet our findings suggest that putting these frameworks into practice in empirical research remains challenging, no doubt because they require a large amount of spatially explicit data on both social and ecological systems collected in multiple locations inside and around PAs. Remote sensing techniques may improve the ability to more clearly define interactive zones and their interactions with PAs (e.g. Alessa, Kliskey, \& Brown, 2008; de Araujo Barbosa, Atkinson, \& Dearing, 2015; Lopez \& Frohn, 2017; Martín-López et al., 2017).

The overall influence of biodiversity and conservation actions on local communities is a second underrepresented research topic (Fig. 8c). In particular, our results demonstrated a divide between studies that investigated the synergies between local people and PAs (e.g. through the maintenance of key natural resources and ecosystem services) and studies that focused on antagonisms between local people and PAs (e.g. through increased humanwildlife conflicts and ecosystem disservices). Of the 240 articles we reviewed, no studies simultaneously investigated synergies and antagonisms between PAs and local people, except to some extent the study of McElwee (2010) in Vietnam. This gap in research, as well as the overrepresentation of studies on human-wildlife conflicts, is likely to explain the apparent overall negative impact of biodiversity around PAs on local livelihoods (Fig. 8c). Addressing this gap is essential to better quantify and reduce the social costs of conservation, while 
reinforcing existing synergies (Naughton-Treves, Alix-Garcia, \& Chapman, 2011). A joint assessment of ecosystem services (i.e. the positive contributions of ecosystems to people's well-being) and disservices (i.e. their negative counterparts) may allow a better understanding of how different stakeholders are affected by the ecological outcomes of PAs (Blanco, Dendoncker, Barnaud, \& Sirami, 2019). This understanding would help improve the overall socio-economic outcomes of PAs, a key step toward more sustainable PA management (Cumming, 2016; Watson et al., 2014).

A third critical challenge is related to the reinforcement of synergies between PAs and local communities. In contrast to the relative success of PAs in protecting ecological systems, their outcomes on social systems appeared to be less positive (Fig. 8c). Two issues may explain this result. Firstly, many PA managers face human and financial resource shortages, which may jeopardize the effectiveness of PAs in conserving biodiversity (Adams, Iacona, \& Possingham, 2019). In this context, the money available may primarily be invested in biodiversity rather than on social actions, leading to a lack of trans-sectorial funding and undermining the alignment of conservation- and agricultural-based actions. Secondly, research efforts may not have been adequate to understand the specificity of each local social system and implement effective site-specific actions. Indeed, social-ecological system approaches are relatively recent, so their outcomes may not be fully visible in the literature yet. Moreover, the dialogue between social scientists and conservationists remains difficult to operationalize (Agrawal \& Ostrom, 2006). Nonetheless, the abundant literature on interdisciplinary approaches based on SES thinking and on ecosystem services provides a sound theoretical and methodological basis to reinforce social sciences in conservation biology research in order to tackle this last challenge (Maestre-Andrés, Calvet-Mir, \& van den Bergh, 2016; Martín-López et al., 2019; Palomo et al., 2014).

\section{Limits in the scope of this review}

While this review enabled us to provide a thorough summary of the current knowledge on terrestrial PA-related interface processes, there were some limitations in its scope. First, we were unable to reach clear conclusions about PA governance issues. This lack of clarity may be partly explained by the strong influence of site-specific factors on relationships between PAs and adjacent human populations, with their different historical legacies, cultural backgrounds and socio-economic dynamics (Ament \& Cumming, 2016; Gardner et al., 2009). In addition, our quantitative approach might have resulted in overlooking some of the less obvious governance processes around PA management that qualitative methods such as discourse analysis may have revealed (e.g. Rodela, 2012). Readers could, however, refer to existing reviews on PA governance issues, such as Reed (2008) or Berkes (2009).

A second limitation was that marine and freshwater PAs were outside the scope of this review, although the associated body of literature may contain key information on interface processes in these systems. In particular, the success of many PAs relies heavily on the management of large watershed areas that cover several administrative units and different types of terrestrial, freshwater and coastal ecosystems (Pallero, Barragán, \& Scherer, 2018). All of these social and ecological units are connected and have varying degrees of protection, which makes understanding their interface processes particularly crucial for managing ecosystems that are simultaneously influenced by terrestrial, freshwater and marine PAs and their stakeholders. Furthermore, promising approaches and methods such as network analyses have been widely used in freshwater and marine PAs, and these could inspire research on terrestrial PAs. For example, these methods have allowed the identification of stakeholders' interests and interactions around PA-related issues such as water pollution (Ruzol, Banzoncabanilla, Ancog, \& Peralta, 2017) and public participation (Nita, Ciocanea, Manolache, \& 
Rozylowicz, 2018). They have allowed the investigation of how mismatches between social and ecological systems affect environmental management and conservation (Bodin, Crona, Thyresson, Golz, \& Tengö, 2014; Sayles \& Baggio, 2017). Developing similar approaches for terrestrial PAs could help navigate the complexity of social systems and identify relevant actions to undertake built on existing local governance or social structures (e.g. Moeliono et al., 2016).

The final limitation was that the query used to select the reviewed literature did not include any specific reference to multi-scale processes and telecoupling interactions, which are, however, key to the success of PAs. The results did reveal evidence about the existence of a 'scale effect' that relates to changes in the observed dynamics according to the spatial scale chosen for the analysis (Ament \& Cumming, 2016). Thus we can conclude that the choice of the scale of sampling according to the research questions requires careful attention. In addition, natural resource governance systems involve multiple actors and institutions, which operate at different levels through both vertical and horizontal interactions (Nunan, 2018). Similarly, while local ecosystems respond to local management practices and ecological processes, they are embedded in larger ecological systems that respond to other types of largescale phenomena, such as climate change or the development of international markets. While these cross-scale interactions were outside the scope of this review, the recent emergence of telecoupling frameworks (Liu et al., 2013; Martín-López et al., 2019) may provide valuable insights about interface processes such as trade flows, information transfer, and species dispersal across scales (see Kapsar et al., 2019 for a review).

\section{Conclusions}

The capacity of protected areas and the areas surrounding them to achieve a diverse set of ecological, social and economic objectives will be crucial to the success and performance of PAs in the Anthropocene (Watson et al., 2014). Meeting this challenge requires an understanding of the interface processes that facilitate, or impede, the coexistence between humans and other species inside and outside PAs; this will involve creating new connections between landscapes with contrasting functions and uses, and between social and ecological sciences. Our review found that consistent advances have been achieved in this perspective, although many research questions persist. The results testify to the existing connections between natural and social sciences, which can be employed together to investigate terrestrial PA-related interface processes and allow a way to examine the complex interdependence between ecosystems and human societies. The findings also indicate that natural sciences have achieved a reasonable understanding of ecosystem functioning that appears to be actionable as shown by the implementation of successful conservation and restoration initiatives. Despite these advances, past and present research effort on interface processes is strongly unbalanced, focusing on a limited number of study sites. Increasing research in underrepresented areas, such as North and West Africa and the Middle East, should be a future priority. We also identified a lack of research concerning cross-boundary interactions (between PAs and their surroundings), particularly regarding the spatial extent of these interactive zones. As biodiversity conservation in the future will increasingly rely on conservation outside PAs (Kremen \& Merenlender, 2018), it seems urgent to better evaluate how protected and unprotected areas influence each other, either through antagonistic or synergistic interactions. Finally, the review highlighted that most related studies on this topic center on biodiversity - there is a lack of research about the socio-economic and cultural outcomes of PAs for people living in their vicinity. In the studies that do exist, the fuzziness of individual research conclusions suggests that generalizable knowledge is lacking that could be scaled up to more systematically ensure the creation of synergies between biodiversity 
conservation and local development. The persistence of the many conflicts inside and around PAs, and the difficulty of reconciling local conservation initiatives with the local people they impact - positively or negatively - are testimony to an incomplete understanding of PAs as social-ecological systems.

\section{Acknowledgements}

This study was supported by the Pays de la Loire regional government (France) in the framework of the international research project CASEST (Anthropogenic Constraints to Tropical Social-Ecological Systems) and by the Brazilian Long-Term Ecological Research platform 'Planalto da Bodoquena: redes de interações em longo Prazo' (PELD-CNPq-Fundect and CAPES/COFECUB Sv 875-17). F.O. Roque received fellowships from the Brazilian National Council for Scientific and Technological Development (CNPq).

\section{References}

Adams, V. M., Iacona, G. D., \& Possingham, H. P. (2019). Weighing the benefits of expanding protected areas versus managing existing ones. Nature Sustainability, 2(5), 404-411. https://doi.org/10.1038/s41893-019-0275-5

Adhikari, S., \& Baral, H. (2018). Governing Forest Ecosystem Services for Sustainable Environmental Governance: A Review. Environments, 5(5), 53. https://doi.org/10.3390/environments5050053

Agrawal, A., \& Ostrom, E. (2006). Political Science and Conservation Biology: a Dialog of the Deaf. Conservation Biology, 20(3), 681-682. https://doi.org/10.1111/j.1523-1739.2006.00468.x

Aldana-Domínguez, J., Montes, C., Martínez, M., Medina, N., Hahn, J., \& Duque, M. (2017). Biodiversity and Ecosystem Services Knowledge in the Colombian Caribbean. Tropical Conservation Science, 10, 194008291771422. https://doi.org/10.1177/1940082917714229

Alessa, L. (Naia), Kliskey, A. (Anaru), \& Brown, G. (2008). Social-ecological hotspots mapping: A spatial approach for identifying coupled social-ecological space. Landscape and Urban Planning, 85(1), 27-39. https://doi.org/10.1016/j.landurbplan.2007.09.007

Altrichter, M. (2005). The sustainability of subsistence hunting of peccaries in the Argentine Chaco. Biological Conservation, 126(3), 351-362. https://doi.org/10.1016/j.biocon.2005.06.024

Ament, J. M., \& Cumming, G. S. (2016). Scale dependency in effectiveness, isolation, and socialecological spillover of protected areas. Conservation Biology, 30(4), 846-855. https://doi.org/10.1111/cobi.12673

Anderson, P. M. L., \& O'Farrell, P. J. (2012). An Ecological View of the History of the City of Cape Town. Ecology and Society, 17(3), art28. https://doi.org/10.5751/ES-04970-170328

Archabald, K., \& Naughton-Treves, L. (2001). Tourism revenue-sharing around national parks in Western Uganda: early efforts to identify and reward local communities. Environmental Conservation, 28(02), 135-149. https://doi.org/10.1017/S0376892901000145

Armenteras, D., Rodríguez, N., \& Retana, J. (2009). Are conservation strategies effective in avoiding the deforestation of the Colombian Guyana Shield? Biological Conservation, 142(7), 1411-1419. https://doi.org/10.1016/j.biocon.2009.02.002

Baird, T. D. (2014). Conservation and Unscripted Development: Proximity to Park Associated with Development and Financial Diversity. Ecology and Society, 19(1), art4. https://doi.org/10.5751/ES-06184-190104

Balme, G. A., Slotow, R., \& Hunter, L. T. B. (2010). Edge effects and the impact of non-protected areas in carnivore conservation: leopards in the Phinda-Mkhuze Complex, South Africa. 
ANIMAL CONSERVATION, 13(3), 315-323. https://doi.org/10.1111/j.1469-1795.2009.00342.x

Beale, C. M., Rensberg, S. Van, Bond, W. J., Coughenour, M., Fynn, R., Gaylard, A., ... Sinclair, A. R. E. (2013). Ten lessons for the conservation of African savannah ecosystems. Biological Conservation, 167, 224-232. https://doi.org/10.1016/j.biocon.2013.08.025

Bennett, E. M., Cramer, W., Begossi, A., Cundill, G., Díaz, S., Egoh, B. N., ... Woodward, G. (2015). Linking biodiversity, ecosystem services, and human well-being: three challenges for designing research for sustainability. Current Opinion in Environmental Sustainability, 14, 76-85. https://doi.org/10.1016/j.cosust.2015.03.007

Berkes, F. (2009). Evolution of co-management: role of knowledge generation, bridging organizations and social learning. Journal of Environmental Management, 90(5), 1692-1702. https://doi.org/10.1016/j.jenvman.2008.12.001

Bhattarai, B. P., \& Kindlmann, P. (2013). Effect of human disturbance on the prey of tiger in the Chitwan National Park - Implications for park management. Journal of Environmental Management, 131, 343-350. https://doi.org/10.1016/j.jenvman.2013.10.005

Blanco, J., Dendoncker, N., Barnaud, C., \& Sirami, C. (2019). Ecosystem disservices matter: Towards their systematic integration within ecosystem service research and policy. Ecosystem Services, 36, 100913. https://doi.org/10.1016/j.ecoser.2019.100913

Bodin, Ö., Crona, B., Thyresson, M., Golz, A. L., \& Tengö, M. (2014). Conservation Success as a Function of Good Alignment of Social and Ecological Structures and Processes. Conservation Biology, 28(5), 1371-1379. https://doi.org/10.1111/cobi.12306

Botha, J., Witkowski, E. T. F., \& Shackleton, C. M. (2004). The impact of commercial harvesting on Warburgia salutaris ('pepper-bark tree') in Mpumalanga, South Africa. Biodiversity and Conservation, 13(9), 1675-1698. https://doi.org/10.1023/B:BIOC.0000029333.72945.b0

Brandt, J. S., Allendorf, T., Radeloff, V., \& Brooks, J. (2017). Effects of national forest-management regimes on unprotected forests of the Himalaya. Conservation Biology, 31(6), 1271-1282. https://doi.org/10.1111/cobi.12927

Carrié, R., Andrieu, E., Ouin, A., \& Steffan-Dewenter, I. (2017). Interactive effects of landscape-wide intensity of farming practices and landscape complexity on wild bee diversity. Landscape Ecology, 32(8), 1631-1642. https://doi.org/10.1007/s10980-017-0530-y

Chamaillé-Jammes, S., Charbonnel, A., Dray, S., Madzikanda, H., \& Fritz, H. (2016). Spatial distribution of a large herbivore community at waterholes: An assessment of its stability over years in Hwange National Park, Zimbabwe. PLoS ONE, 11(4), 1-13. https://doi.org/10.1371/journal.pone.0153639

Chapple, R. S., Ramp, D., Bradstock, R. A., Kingsford, R. T., Merson, J. A., Auld, T. D., ... Mulley, R. C. (2011). Integrating Science into Management of Ecosystems in the Greater Blue Mountains. Environmental Management, 48(4), 659-674. https://doi.org/10.1007/s00267-0119721-5

Cumming, G. S. (2016). The relevance and resilience of protected areas in the Anthropocene. Anthropocene, 13, 46-56. https://doi.org/10.1016/j.ancene.2016.03.003

Dallimer, M., \& King, T. (2008). Habitat preferences of the forest birds on the island of Príncipe, Gulf of Guinea. African Journal of Ecology, 46(3), 258-266. https://doi.org/10.1111/j.13652028.2007.00891.x

Danby, R. K., \& Slocombe, D. S. (2005). Regional ecology, ecosystem geography, and transboundary protected areas in the St. Elias mountains. Ecological Applications, 15(2), 405-422.

https://doi.org/10.1890/04-0043 
de Araujo Barbosa, C. C., Atkinson, P. M., \& Dearing, J. A. (2015). Remote sensing of ecosystem services: A systematic review. Ecological Indicators, 52, 430-443.

https://doi.org/10.1016/j.ecolind.2015.01.007

DeFries, R, Karanth, K. K., \& Pareeth, S. (2010). Interactions between protected areas and their surroundings in human-dominated tropical landscapes. Biological Conservation, 143(12), 2870 2880. https://doi.org/10.1016/j.biocon.2010.02.010

DeFries, Ruth, Rovero, F., Wright, P., Ahumada, J., Andelman, S., Brandon, K., ... Liu, J. (2010). From plot to landscape scale: linking tropical biodiversity measurements across spatial scales. Frontiers in Ecology and the Environment, 8(3), 153-160. https://doi.org/10.1890/080104

Di Marco, M., Chapman, S., Althor, G., Kearney, S., Besancon, C., Butt, N., ... Watson, J. E. M. (2017). Changing trends and persisting biases in three decades of conservation science. Global Ecology and Conservation, 10, 32-42. https://doi.org/10.1016/j.gecco.2017.01.008

Dickman, A. J., Hazzah, L., Carbone, C., \& Durant, S. M. (2014). Carnivores, culture and "contagious conflict": Multiple factors influence perceived problems with carnivores in Tanzania's Ruaha landscape. Biological Conservation, 178, 19-27. https://doi.org/10.1016/j.biocon.2014.07.011

Driscoll, D. A., Banks, S. C., Barton, P. S., Lindenmayer, D. B., \& Smith, A. L. (2013). Conceptual domain of the matrix in fragmented landscapes. Trends in Ecology \& Evolution, 28(10), 605613. https://doi.org/10.1016/j.tree.2013.06.010

Ellis, E. A., \& Porter-Bolland, L. (2008). Is community-based forest management more effective than protected areas?. A comparison of land use/land cover change in two neighboring study areas of the Central Yucatan Peninsula, Mexico. Forest Ecology and Management, 256(11), 1971-1983. https://doi.org/10.1016/j.foreco.2008.07.036

Fernández-Juricic, E., Vaca, R., \& Schroeder, N. (2004). Spatial and temporal responses of forest birds to human approaches in a protected area and implications for two management strategies. Biological Conservation, 117(4), 407-416. https://doi.org/10.1016/j.biocon.2003.02.001

Fernández, J. D., \& Gómez, J. M. (2012). Advantages and drawbacks of living in protected areas: The case of the threatened Erysimum popovii (Brassicaceae) in SE Iberian Peninsula. Biodiversity and Conservation, 21(10), 2539-2554. https://doi.org/10.1007/s10531-012-0316-0

Fischer, J., Abson, D. J., Bergsten, A., French Collier, N., Dorresteijn, I., Hanspach, J., ... Senbeta, F. (2017). Reframing the Food-Biodiversity Challenge. Trends in Ecology \& Evolution, 32(5), 335-345. https://doi.org/10.1016/j.tree.2017.02.009

Forbes, S. H., \& Boyd, D. K. (1996). Genetic variation of naturally colonizing wolves in the Central Rocky Mountains. CONSERVATION BIOLOGY, 10(4), 1082-1090. https://doi.org/10.1046/j.1523-1739.1996.10041082.x

Gardner, T. A., Barlow, J., Chazdon, R., Ewers, R. M., Harvey, C. A., Peres, C. A., \& Sodhi, N. S. (2009). Prospects for tropical forest biodiversity in a human-modified world. Ecology Letters, 12(6), 561-582. https://doi.org/10.1111/j.1461-0248.2009.01294.x

Godet, L., \& Devictor, V. (2018). What Conservation Does. Trends in Ecology \& Evolution, 33(10), 720-730. https://doi.org/10.1016/j.tree.2018.07.004

Gonzalez, A., Thompson, P., \& Loreau, M. (2017). Spatial ecological networks: planning for sustainability in the long-term. Current Opinion in Environmental Sustainability, 29, 187-197. https://doi.org/10.1016/j.cosust.2018.03.012

Gray, C. L., Hill, S. L. L., Newbold, T., Hudson, L. N., Boïrger, L., Contu, S., .. Scharlemann, J. P. W. (2016). Local biodiversity is higher inside than outside terrestrial protected areas worldwide. Nature Communications, 7(May). https://doi.org/10.1038/ncomms12306 
Gurd, D. B., Nudds, T. D., \& Rivard, D. H. (2001). Conservation of Mammals in Eastern North American Wildlife Reserves: How Small Is Too Small? Conservation Biology, 15(5), 13551363. https://doi.org/10.1046/j.1523-1739.2001.00188.x

Haddad, N. M., Brudvig, L. A., Clobert, J., Davies, K. F., Gonzalez, A., Holt, R. D., ... Townshend, J. R. (2015). Habitat fragmentation and its lasting impact on Earth's ecosystems. Science Advances, l(2), e1500052. https://doi.org/10.1126/sciadv.1500052

Haggar, J., Asigbaase, M., Bonilla, G., Pico, J., \& Quilo, A. (2015). Tree diversity on sustainably certified and conventional coffee farms in Central America. Biodiversity and Conservation, 24(5), 1175-1194. https://doi.org/10.1007/s10531-014-0851-y

Hansen, A. J., \& DeFries, R. (2007). Ecological mechanisms linking protected areas to surrounding lands. Ecological Applications, 17(4), 974-988. https://doi.org/10.1890/05-1098

Harihar, A., Pandav, B., \& Goyal, S. P. (2011). Responses of leopard Panthera pardus to the recovery of a tiger Panthera tigris population. Journal of Applied Ecology, 48(3), 806-814. https://doi.org/10.1111/j.1365-2664.2011.01981.x

Hoa Hong Dao, T., \& Hölscher, D. (2015). Red-Listed Tree Species Abundance in Montane Forest Areas with Differing Levels of Statutory Protection in North-Western Vietnam. Tropical Conservation Science, 8(2), 479-490. https://doi.org/10.1177/194008291500800212

IPBES. (2019). Global assessment report on biodiversity and ecosystem services of the Intergovernmental Science- Policy Platform on Biodiversity and Ecosystem Services. (E. S. Brondizio, J. Settele, S. Díaz, \& H. T. Ngo, Eds.). Bonn, Germany: IPBES Secretariat.

Jusys, T. (2016). Quantifying avoided deforestation in Pará: Protected areas, buffer zones and edge effects. Journal for Nature Conservation, 33, 10-17. https://doi.org/10.1016/j.jnc.2016.05.001

Kapsar, K. E., Hovis, C. L., da Silva, R. F. B., Buchholtz, E. K., Carlson, A. K., Dou, Y., ... Liu, J. (2019). Telecoupling research: The first five years. Sustainability (Switzerland), 11(4), 1-13. https://doi.org/10.3390/su11041033

Karanth, K. K., Naughton-Treves, L., Defries, R., \& Gopalaswamy, A. M. (2013). Living with wildlife and mitigating conflicts around three indian protected areas. Environmental Management, 52(6), 1320-1332. https://doi.org/10.1007/s00267-013-0162-1

Kinnaird, M. F., Sanderson, E. W., O’Brien, T. G., Wibisono, H. T., \& Woolmer, G. (2003). Deforestation Trends in a Tropical Landscape and Implications for Endangered Large Mammals. Conservation Biology, 17(1), 245-257. https://doi.org/10.1046/j.1523-1739.2003.02040.x

Kintz, D. B., Young, K. R., \& Crews-Meyer, K. A. (2006). Implications of Land Use/Land Cover Change in the Buffer Zone of a National Park in the Tropical Andes. Environmental Management, 38(2), 238-252. https://doi.org/10.1007/s00267-005-0147-9

Kremen, C., \& Merenlender, A. M. (2018). Landscapes that work for biodiversity and people. Science, 362(6412). https://doi.org/10.1126/science.aau6020

Lagendijk, D. D. G., \& Gusset, M. (2008). Human-Carnivore Coexistence on Communal Land Bordering the Greater Kruger Area, South Africa. Environmental Management, 42(6), 971-976. https://doi.org/10.1007/s00267-008-9204-5

Lehikoinen, P., Santangeli, A., Jaatinen, K., Rajasärkkä, A., \& Lehikoinen, A. (2019). Protected areas act as a buffer against detrimental effects of climate change-Evidence from large-scale, longterm abundance data. Global Change Biology, 25(1), 304-313. https://doi.org/10.1111/gcb.14461

Leigh, S. G., Smart, J., \& Gill, J. A. (2017). Impacts of grassland management on wader nest predation rates in adjacent nature reserves. Animal Conservation, 20(1), 61-71. 
https://doi.org/10.1111/acv.12283

Liu, J., Hull, V., Batistella, M., DeFries, R., Dietz, T., Fu, F., ... Zhu, C. (2013). Framing Sustainability in a Telecoupled World. Ecology and Society, 18(2), art26. https://doi.org/10.5751/ES-05873-180226

Lopez, R. D., \& Frohn, R. C. (2017). Remote Sensing for Landscape Ecology. (R. D. Lopez \& R. C. Frohn, Eds.). Boca Raton: Routledge. https://doi.org/10.1201/9781315152714

Maestre-Andrés, S., Calvet-Mir, L., \& van den Bergh, J. C. J. M. (2016). Sociocultural valuation of ecosystem services to improve protected area management: a multi-method approach applied to Catalonia, Spain. Regional Environmental Change, 16(3), 717-731. https://doi.org/10.1007/s10113-015-0784-3

Magige, F., \& Senzota, R. (2006). Abundance and diversity of rodents at the human-wildlife interface in Western Serengeti, Tanzania. African Journal of Ecology, 44(3), 371-378. https://doi.org/10.1111/j.1365-2028.2006.00641.x

Martín-López, B., Felipe-Lucia, M. R., Bennett, E. M., Norström, A., Peterson, G., Plieninger, T., ... Locatelli, B. (2019). A novel telecoupling framework to assess social relations across spatial scales for ecosystem services research. Journal of Environmental Management, 241(March), 251-263. https://doi.org/10.1016/j.jenvman.2019.04.029

Martín-López, B., Palomo, I., García-Llorente, M., Iniesta-Arandia, I., Castro, A. J., García Del Amo, D., ... Montes, C. (2017). Delineating boundaries of social-ecological systems for landscape planning: A comprehensive spatial approach. Land Use Policy, 66(August 2016), 90-104. https://doi.org/10.1016/j.landusepol.2017.04.040

Mathevet, R., Thompson, J. D., Folke, C., \& Chapin, F. S. (2016). Protected areas and their surrounding territory: socioecological systems in the context of ecological solidarity. Ecological Applications, 26(1), 5-16. https://doi.org/10.1890/14-0421

McElwee, P. D. (2010). Resource Use Among Rural Agricultural Households Near Protected Areas in Vietnam: The Social Costs of Conservation and Implications for Enforcement. Environmental Management, 45(1), 113-131. https://doi.org/10.1007/s00267-009-9394-5

Mgawe, P., Mulder, M. B., Caro, T., Martin, A., \& Kiffner, C. (2012). Factors Affecting Bushmeat Consumption in the Katavi-Rukwa Ecosystem of Tanzania. Tropical Conservation Science, 5(4), 446-462. https://doi.org/10.1177/194008291200500404

Moeliono, M., Pham, T. T., Le, N. D., Brockhaus, M., Wong, G., Kallio, M., \& Nguyen, D. T. (2016). Local Governance, Social Networks and REDD+: Lessons from Swidden Communities in Vietnam. Human Ecology. https://doi.org/10.1007/s10745-016-9839-4

Mondal, P, \& Southworth, J. (2010). Protection vs. commercial management: Spatial and temporal analysis of land cover changes in the tropical forests of Central India. Forest Ecology and Management, 259(5), 1009-1017. https://doi.org/10.1016/j.foreco.2009.12.007

Mondal, Pinki, \& Southworth, J. (2010). Evaluation of conservation interventions using a cellular automata-Markov model. Forest Ecology and Management, 260(10), 1716-1725. https://doi.org/10.1016/j.foreco.2010.08.017

Murungweni, C., van Wijk, M. T., Andersson, J. A., Smaling, E. M. A., \& Giller, K. E. (2011). Application of Fuzzy Cognitive Mapping in Livelihood Vulnerability Analysis. Ecology and Society, 16(4), art8. https://doi.org/10.5751/ES-04393-160408

Mworia, J. K., Kinyamario, J. I., \& Githaiga, J. M. (2008). Influence of cultivation, settlements and water sources on wildlife distribution and habitat selection in south-east Kajiado, Kenya. Environmental Conservation, 35(2), 117-124. https://doi.org/10.1017/S0376892908004670 
Naughton-Treves, L., Alix-Garcia, J., \& Chapman, C. A. (2011). Lessons about parks and poverty from a decade of forest loss and economic growth around Kibale National Park, Uganda. Proceedings of the National Academy of Sciences, 108(34), 13919-13924. https://doi.org/10.1073/pnas.1013332108

Nepal, S. K. (2002). Involving Indigenous Peoples in Protected Area Management: Comparative Perspectives from Nepal, Thailand, and China. Environmental Management, 30(6), 748-763. https://doi.org/10.1007/s00267-002-2710-y

Newmark, W D, Leonard, N. L., Sariko, H. I., \& Gamassa, D.-G. M. (1993). Conservation attitudes of local people living adjacent to five protected areas in Tanzania. Biological Conservation, 63(2), 177-183. https://doi.org/10.1016/0006-3207(93)90507-W

Newmark, William D. (2008). Isolation of African protected areas. Frontiers in Ecology and the Environment, 6(6), 321-328. https://doi.org/10.1890/070003

Newmark, William D., Boshe, J. I., Sariko, H. I., \& Makumbule, G. K. (1996). Effects of a highway on large mammals in Mikumi National Park, Tanzania. African Journal of Ecology, 34(1), 1531. https://doi.org/10.1111/j.1365-2028.1996.tb00590.x

Nita, A., Ciocanea, C. M., Manolache, S., \& Rozylowicz, L. (2018). A network approach for understanding opportunities and barriers to effective public participation in the management of protected areas. Social Network Analysis and Mining, 8(1), 1-11. https://doi.org/10.1007/s13278018-0509-y

Nunan, F. (2018). Navigating multi-level natural resource governance: An analytical guide. Natural Resources Forum, 42, 159-171. https://doi.org/10.1111/1477-8947.12149

Nyhus, P. J., Sumianto, \& Tilson, R. (2003). Wildlife knowledge among migrants in southern Sumatra, Indonesia: implications for conservation. Environmental Conservation, 30(2), S0376892903000183. https://doi.org/10.1017/S0376892903000183

Pallero, C., Barragán, J. M., \& Scherer, M. (2018). Management international estuarine systems: The case of the Guadiana river (Spain-Portugal). Environmental Science \& Policy, 80(November 2017), 82-94. https://doi.org/10.1016/j.envsci.2017.11.005

Palomo, I., Montes, C., Martín-López, B., González, J. A., García-Llorente, M., Alcorlo, P., \& Mora, M. R. G. (2014). Incorporating the social-ecological approach in protected areas in the anthropocene. BioScience. https://doi.org/10.1093/biosci/bit033

Petracca, L. S., Hernández-Potosme, S., Obando-Sampson, L., Salom-Pérez, R., Quigley, H., \& Robinson, H. S. (2014). Agricultural encroachment and lack of enforcement threaten connectivity of range-wide jaguar (Panthera onca) corridor. Journal for Nature Conservation, 22(5), 436-444. https://doi.org/10.1016/j.jnc.2014.04.002

Porter-Bolland, L., Ellis, E. A., Guariguata, M. R., Ruiz-Mallen, I., Negrete-Yankelevich, S., \& Reyes-Garcia, V. (2012). Community managed forests and forest protected areas: An assessment of their conservation effectiveness across the tropics. Forest Ecology and Management, 268, 617. https://doi.org/10.1016/j.foreco.2011.05.034

Ramankutty, N., Mehrabi, Z., Waha, K., Jarvis, L., Kremen, C., Herrero, M., \& Rieseberg, L. H. (2018). Trends in Global Agricultural Land Use: Implications for Environmental Health and Food Security. Annual Review of Plant Biology, 69(1), annurev-arplant-042817-040256. https://doi.org/10.1146/annurev-arplant-042817-040256

Reed, M. S. (2008). Stakeholder participation for environmental management: A literature review. Biological Conservation, 141(10), 2417-2431. https://doi.org/10.1016/j.biocon.2008.07.014

Reyna-Hurtado, R. (2009). Conservation Status of the White-Lipped Peccary (Tayassu Pecari) Outside the Calakmul Biosphere Reserve in Campeche, Mexico: A Synthesis. Tropical Conservation 
Science, 2(2), 159-172. https://doi.org/10.1177/194008290900200204

Rodela, R. (2012). Advancing the deliberative turn in natural resource management: An analysis of discourses on the use of local resources. Journal of Environmental Management, 96(1), 26-34. https://doi.org/10.1016/j.jenvman.2011.10.013

Román-Cuesta, R. M., \& Martínez-Vilalta, J. (2006). Effectiveness of Protected Areas in Mitigating Fire within Their Boundaries: Case Study of Chiapas, Mexico. Conservation Biology, 20(4), 1074-1086. https://doi.org/10.1111/j.1523-1739.2006.00478.x

Ruzol, C., Banzon-cabanilla, D., Ancog, R., \& Peralta, E. (2017). Understanding water pollution management : Evidence and insights from incorporating cultural theory in social network analysis. Global Environmental Change, 45(September 2016), 183-193. https://doi.org/10.1016/j.gloenvcha.2017.06.009

Sarker, A. H. M. R., \& Røskaft, E. (2010). Human-wildlife conflicts and management options in Bangladesh, with special reference to Asian elephants (Elephas maximus). International Journal of Biodiversity Science, Ecosystem Services and Management, 6(3-4), 164-175. https://doi.org/10.1080/21513732.2011.554867

Sayles, J. S., \& Baggio, J. A. (2017). Social-ecological network analysis of scale mismatches in estuary watershed restoration. Proceedings of the National Academy of Sciences, 114(10), E1776-E1785. https://doi.org/10.1073/pnas.1604405114

Seiler, N., \& Robbins, M. M. (2016). Factors Influencing Ranging on Community Land and Crop Raiding by Mountain Gorillas. Animal Conservation, 19(2), 176-188. https://doi.org/10.1111/acv.12232

Shackleton, C. M., Ruwanza, S., Sinasson Sanni, G. K., Bennett, S., De Lacy, P., Modipa, R., ... Thondhlana, G. (2016). Unpacking Pandora's Box: Understanding and Categorising Ecosystem Disservices for Environmental Management and Human Wellbeing. Ecosystems, 19(4), 587-600. https://doi.org/10.1007/s10021-015-9952-z

Shafer, C. L. (2015). Cautionary thoughts on IUCN protected area management categories V-VI. Global Ecology and Conservation, 3, 331-348. https://doi.org/10.1016/j.gecco.2014.12.007

Shova, T., \& Hubacek, K. (2011). Drivers of illegal resource extraction: An analysis of Bardia National Park, Nepal. Journal of Environmental Management, 92(1), 156-164. https://doi.org/10.1016/j.jenvman.2010.08.021

Spellerberg, I. F. (1998). Ecological Effects of Roads and Traffic: A Literature Review. Global Ecology and Biogeography Letters, 7(5), 317. https://doi.org/10.2307/2997681

Stronen, A. V., Brook, R. K., Paquet, P. C., \& Mclachlan, S. (2007). Farmer attitudes toward wolves: Implications for the role of predators in managing disease. Biological Conservation, 135(1), 110. https://doi.org/10.1016/j.biocon.2006.09.012

Studsrød, J. E., \& Wegge, P. (1995). Park-People Relationships: The Case of Damage Caused by Park Animals Around the Royal Bardia National Park, Nepal. Environmental Conservation, 22(2), 133-142. https://doi.org/10.1017/S0376892900010183

Thoms, C. a. (2008). Community control of resources and the challenge of improving local livelihoods: A critical examination of community forestry in Nepal. Geoforum, 39(3), 14521465. https://doi.org/10.1016/j.geoforum.2008.01.006

Thorn, S., Bässler, C., Svoboda, M., \& Müller, J. (2017). Effects of natural disturbances and salvage logging on biodiversity - Lessons from the Bohemian Forest. Forest Ecology and Management, 388, 113-119. https://doi.org/10.1016/j.foreco.2016.06.006

UNEP-WCMC, \& IUCN. (2016). Protected Planet Report 2016. Cambridge UK and Gland, 
Switzerland: UNEP-WCMC and IUCN. https://doi.org/10.1086/429577

UNEP-WCMC, \& IUCN. (2018). Protected Planet: The World Database on Protected Areas (WDPA). Retrieved from www.protectedplanet.net

van Eck, N. J., \& Waltman, L. (2010). Software survey: VOSviewer, a computer program for bibliometric mapping. Scientometrics, 84(2), 523-538. https://doi.org/10.1007/s11192-009-01463

Walpole, M. J., \& Goodwin, H. J. (2001). Local attitudes towards conservation and tourism around Komodo National Park, Indonesia. Environmental Conservation, 28(02), 160-166. https://doi.org/10.1017/S0376892901000169

Waltman, L., van Eck, N. J., \& Noyons, E. C. M. (2010). A unified approach to mapping and clustering of bibliometric networks. Journal of Informetrics, 4(4), 629-635. https://doi.org/10.1016/j.joi.2010.07.002

Watson, J. E. M., Dudley, N., Segan, D. B., \& Hockings, M. (2014). The performance and potential of protected areas. Nature, 515(7525), 67-73. https://doi.org/10.1038/nature13947

Wegge, P., Yadav, S. K., \& Lamichhane, B. R. (2018). Are corridors good for tigers Panthera tigris but bad for people? An assessment of the Khata corridor in lowland Nepal. Oryx, 52(1), 35-45. https://doi.org/10.1017/S0030605316000661

Woodroffe, R., Lindsey, P., Romañach, S., Stein, A., \& Ole Ranah, S. M. K. (2005). Livestock predation by endangered African wild dogs (Lycaon pictus) in northern Kenya. Biological Conservation, 124(2), 225-234. https://doi.org/10.1016/j.biocon.2005.01.028

Zhou, D., Wang, Z., Lassoie, J., Wang, X., \& Sun, L. (2014). Changing stakeholder relationships in nature reserve management: A case study on snake island-laotie mountain national nature reserve, liaoning, china. Journal of Environmental Management, 146, 292-302. https://doi.org/10.1016/j.jenvman.2014.07.018 
Table S1 Standardized queries targeting the literature on protected areas (PAs) and PA-related interface processes, and main characteristics of the two resulting literature corpuses. Search was performed on November 2nd 2018 in the Web of Science's Core database.

\begin{tabular}{|c|c|c|}
\hline & Literature on PA & Literature on PA-related interface processes \\
\hline Queries $^{\text {II }}$ & $\begin{array}{l}\text { 1) Selection of different types of protected } \\
\text { areas: } \\
\text { TS=("conservation area*" OR "protected } \\
\text { area*" OR "national park*" OR "natur* } \\
\text { reserve*" OR "wilderness area*" OR } \\
\text { "biosphere reserve*") } \\
\text { 2) Exclusion of marine and urban PAs } \\
\text { NOT TS=("marine" OR "urban protected" } \\
\text { OR "urban conservation") }\end{array}$ & $\begin{array}{l}\text { 1) Selection of proximity adjectives...: } \\
\text { TS=((around OR edge OR adjacent OR "near" OR } \\
\text { surrounding* OR border* OR periphery OR boundary } \\
\text { OR adjoining) } \\
\text { 2) ... appearing close to a type of PAs (marine and } \\
\text { urban PAs excluded) } \\
\text { NEAR/3 ("conservation area*" OR "protected area*" } \\
\text { OR "national park*" OR "natur* reserve*" OR } \\
\text { "wilderness area*" OR "biosphere reserve*")) NOT } \\
\text { TS=("marine" OR "urban protected" OR "urban } \\
\text { conservation") } \\
\text { 3) Selection of concepts designating PA interactive } \\
\text { zones and social-ecological interactions...: } \\
\text { TS=("buffer zone*" OR "buffer area*" OR } \\
\text { "interface*" OR "co-occurrence area*" OR "social- } \\
\text { ecological" OR "socio-ecological" OR "socio- } \\
\text { ecosystem") } \\
\text { 4) ...occurring together with a type of PAs (marine } \\
\text { and urban PAs excluded): } \\
\text { AND TS=("conservation area*" OR "protected area*" } \\
\text { OR "national park*" OR "natur* reserve*" OR } \\
\text { "wilderness area*" OR "biosphere reserve*") NOT } \\
\text { TS=("marine" OR "urban protected" OR "urban } \\
\text { conservation") }\end{array}$ \\
\hline $\begin{array}{l}\text { No of papers } \\
\text { including: } \\
\text { - articles } \\
\text { - reviews }\end{array}$ & $\begin{array}{c}37,436 \\
1,322\end{array}$ & $\begin{array}{c}3,151 \\
105\end{array}$ \\
\hline $\begin{array}{l}\text { No of citations } \\
\text { - average } \\
\text { - most cited } \\
\end{array}$ & $\begin{array}{c}18.4 \\
2,316\end{array}$ & $\begin{array}{c}17.0 \\
1,166\end{array}$ \\
\hline $\begin{array}{l}\text { Main authors } \\
\text { (No of papers) }\end{array}$ & $\begin{array}{l}\text { Chapman, C.A. (173) } \\
\text { Macdonald, D.W. (124) } \\
\text { Boesch, C. (88) }\end{array}$ & $\begin{array}{l}\text { Chapman, C.A. (21) } \\
\text { Radeloff, V.C. (21) } \\
\text { Macdonald, D.W. (20) }\end{array}$ \\
\hline $\begin{array}{l}\text { Main journals } \\
\text { (No of papers) }\end{array}$ & $\begin{array}{c}\text { Biological Conservation }(1,354) \\
\text { Biodiversity and Conservation (806) } \\
\text { Forest ecology and management (787) }\end{array}$ & $\begin{array}{c}\text { Biological conservation (199) } \\
\text { Conservation Biology (98) } \\
\text { ORYX (95) }\end{array}$ \\
\hline
\end{tabular}


Table S2 List of the components and interactions (i.e. processes) that had been studied in the 240 research articles analysed, and observed trends. " $n$ " represents the number of time each type of process had been studied.

\begin{tabular}{|c|c|c|c|c|c|}
\hline Studied processes organized in categories & $\mathbf{n}$ & $\begin{array}{c}\text { Negative } \\
\text { trend }\end{array}$ & $\begin{array}{c}\text { Neutral } \\
\text { trend }\end{array}$ & $\begin{array}{c}\text { Positive } \\
\text { trend }\end{array}$ & $\begin{array}{c}\text { Multiple } \\
\text { trends }\end{array}$ \\
\hline Biodiversity \& its distribution across landscapes & 90 & & & & \\
\hline Animal populations, distributions \& dynamics & 72 & $4 \%$ & $88 \%$ & $6 \%$ & $3 \%$ \\
\hline Plant populations, distributions \& dynamics & 18 & $6 \%$ & $78 \%$ & $6 \%$ & $11 \%$ \\
\hline Landscape and habitat characteristics \& dynamics & 19 & & & & \\
\hline Landscape characteristics (incl. LULC \& habitats) & 6 & - & $100 \%$ & - & - \\
\hline Landscape changes (incl. LULCC) & 13 & - & $85 \%$ & $8 \%$ & $8 \%$ \\
\hline Ecosystem service assessments & 3 & & & & \\
\hline Ecosystem service assessments \& evolution & 3 & - & $33 \%$ & - & $67 \%$ \\
\hline Local human activities \& livelihoods & 44 & & & & \\
\hline Local agro-pastoral systems \& their drivers & 5 & $20 \%$ & $80 \%$ & - & - \\
\hline $\begin{array}{l}\text { Socio-economic situation and/or activities of local } \\
\text { people }\end{array}$ & 4 & - & $100 \%$ & - & \\
\hline Socio-economic drivers of other local activities & 10 & - & $50 \%$ & $10 \%$ & $40 \%$ \\
\hline Local ecological knowledge \& use of biodiversity & 25 & $4 \%$ & $92 \%$ & - & $4 \%$ \\
\hline Human influence on biodiversity \& landscapes & 71 & & & & \\
\hline $\begin{array}{l}\text { Agro-pastoral practices influence on biodiversity \& } \\
\text { habitats }\end{array}$ & 9 & $44 \%$ & $11 \%$ & $11 \%$ & $33 \%$ \\
\hline $\begin{array}{l}\text { Human infrastructure \& land use intensity influence on } \\
\text { biodiversity }\end{array}$ & 23 & $61 \%$ & $13 \%$ & - & $26 \%$ \\
\hline Logging effect on biodiversity $\&$ habitats & 7 & $57 \%$ & $29 \%$ & - & $14 \%$ \\
\hline Socio-economic drivers of LULC change & 10 & $30 \%$ & $50 \%$ & - & $20 \%$ \\
\hline $\begin{array}{l}\text { Other human practices influence on biodiversity \& } \\
\text { habitats }\end{array}$ & 22 & $55 \%$ & $18 \%$ & - & $27 \%$ \\
\hline Biodiversity influence on local activities $\&$ livelihoods & 19 & & & & \\
\hline Perceptions \& attitudes toward wildlife & 9 & $33 \%$ & $11 \%$ & $22 \%$ & $33 \%$ \\
\hline Biodiversity impact on humans \& agro-pastoral systems & 10 & $80 \%$ & $20 \%$ & - & - \\
\hline Conservation effect on biodiversity & 40 & & & & \\
\hline PA effect on biodiversity (species and populations) & 31 & $13 \%$ & $26 \%$ & $52 \%$ & \\
\hline Protection regimes effect on biodiversity & 9 & $11 \%$ & $33 \%$ & $44 \%$ & \\
\hline Conservation effect on land use $\&$ habitats & 35 & & & & \\
\hline PA effect on land use/cover \& habitats & 20 & $10 \%$ & $20 \%$ & $40 \%$ & $30 \%$ \\
\hline Protection regimes effect on land use/cover \& habitats & 15 & $13 \%$ & $33 \%$ & $47 \%$ & $7 \%$ \\
\hline Conservation effect on local livelihoods \& development & 9 & & & & \\
\hline PA effect on population livelihoods \& development & 9 & - & $33 \%$ & $33 \%$ & $33 \%$ \\
\hline $\begin{array}{l}\text { Conservation governance \& relationships with local } \\
\text { people }\end{array}$ & 61 & & & & \\
\hline Perceptions \& attitudes toward conservation tools & 36 & $19 \%$ & $11 \%$ & $39 \%$ & $31 \%$ \\
\hline Local populations interactions with PA governance & 10 & $20 \%$ & $40 \%$ & $10 \%$ & $30 \%$ \\
\hline PA governance processes \& challenges & 14 & - & $79 \%$ & $7 \%$ & $14 \%$ \\
\hline Other & 12 & - & - & - & \\
\hline Total & 403 & - & - & - & \\
\hline
\end{tabular}


Table S3 List of the different definitions found in the 240 research articles. Definitions were found only for "buffer areas" and "buffer zones".

\begin{tabular}{cl}
$\begin{array}{c}\text { Concept } \\
\text { used }\end{array}$ & \multicolumn{1}{c}{ Definitions/descriptions } \\
\hline $\begin{array}{c}\text { Buffer } \\
\text { area }\end{array}$ & $\begin{array}{l}\text { "Areas where human activity is restricted, to reduce human disturbance } \\
\text { on wildlife" }\end{array}$ \\
\hline & $\begin{array}{l}\text { "where conservation is emphasized, but sustainable land use and } \\
\text { tourism are allowed" }\end{array}$ \\
& "where resident resource needs could not be met by existing resources in \\
the peripheral area outside the Park" & "where some low intensity uses are permitted in order to maintain local \\
& $\begin{array}{l}\text { livelihoods and traditions while reducing anthropogenic pressures on } \\
\text { protected core areas" }\end{array}$ \\
& "It has some allowable human activities, thereby aspiring to soften the \\
& impact of human activities from the human activity zone on the core \\
& zone" \\
& "restrict access to specified areas and specified periods of time"
\end{tabular}

"allows low-impact activities in the form of sustainable land use and has the function of protecting the core area from high human impact"

References

(Fernández-Juricic, Venier, Renison, \& Blumstein, 2005)

(Kuemmerle, Hostert, Radeloff, Perzanowski, \& Kruhlov, 2007)

(ORMSBY \& KAPLIN, 2005)

(Hoa Hong Dao \& Hölscher, 2015)

(Xu et al., 2016)

(Fernández-Juricic, Vaca, \& Schroeder, 2004)

(Mehring \& Stoll-

Kleemann, 2011)

"Areas adjacent to protected areas, on which land use is partially restricted to give an added layer of protection to the protected area itself while providing valued benefits to neighboring rural communities"

"restrict access around individual nests. The size of the buffer zone depends on the species' sensitivity to disturbance, type of disturbance, and nest location"

"which is supposed to reduce the effect of people on the core area of the park"

(Weisse \& Naughton-

Treves, 2016)

(Cruz et al., 2018)

"in which particular attention is paid to limiting future growth in, and where possible reducing, artificial nighttime lighting"

"mosaics of managed vegetation that provide a physical buffer to the core. They not only insulate the core protected area from outside disturbance, but also facilitate an extension of the ecosystem processes and functions of the core area"

"meant to protect its conservation unit from deforestation rather than itself, to reduce edge effects, to protect from gold mining, drug cultivation, poaching and maintaining viable population of species"

"Transition zone between human settlements and protected area"

(Bhattarai \&

Kindlmann, 2013)

(Gaston, Duffy, \&

Bennie, 2015)

(Shyamsundar, 1996)

(Jusys, 2016)

(Sarker \& Røskaft, 2011)

"where limited human activities are allowed but are controlled by the reserve management"

(Grill \& Cleary, 2003)

"managed by the Deparment of Forestry, from which communities can legally extract resources"

(Allendorf et al., 2006)

"where certain controlled uses are also desirable and taken into consideration"

(Krishna, Chhetri, \& Singh, 2006) 
"within which the sustainable use of natural resources is allowed"

"has allowed low levels of agriculture, logging, mining and hunting"

"an area of controlled and sustainable land-use, which separates a protected area from direct human or other pressure and provides valued benefits to neighbouring rural communities"

"a management strategy to reduce the influence of surrounding land-use activity on biodiversity within the protected area"
(Blom, van Zalinge, Heitkönig, \& Prins, 2005)

(Licona, McCleery, Collier, Brightsmith, \& Lopez, 2011)

(Nepal \& Weber, 1994)

(Kintz, Young, \& Crews-Meyer, 2006)

Interface No definition/description found

\section{Cited references:}

Allendorf, T., Swe, K. K., Oo, T., Htut, Y., Aung, M., Aung, M., ... Wemmer, C. (2006). Community attitudes toward three protected areas in Upper Myanmar (Burma). Environmental Conservation, 33(04), 344. https://doi.org/10.1017/S0376892906003389

Bhattarai, B. P., \& Kindlmann, P. (2013). Effect of human disturbance on the prey of tiger in the Chitwan National Park - Implications for park management. Journal of Environmental Management, 131, 343-350. https://doi.org/10.1016/j.jenvman.2013.10.005

Blom, A., van Zalinge, R., Heitkönig, I. M. A., \& Prins, H. H. T. (2005). Factors influencing the distribution of large mammals within a protected central African forest. Oryx, 39(04), 381. https://doi.org/10.1017/S0030605305001080

Cruz, J., Windels, S. K., Thogmartin, W. E., Crimmins, S. M., Grim, L. H., \& Zuckerberg, B. (2018). Managing individual nests promotes population recovery of a top predator. Journal of Applied Ecology, 55(3), 1418-1429. https://doi.org/10.1111/1365-2664.13062

Fernández-Juricic, E., Vaca, R., \& Schroeder, N. (2004). Spatial and temporal responses of forest birds to human approaches in a protected area and implications for two management strategies. Biological Conservation, 117(4), 407-416. https://doi.org/10.1016/j.biocon.2003.02.001

Fernández-Juricic, E., Venier, M. P., Renison, D., \& Blumstein, D. T. (2005). Sensitivity of wildlife to spatial patterns of recreationist behavior: A critical assessment of minimum approaching distances and buffer areas for grassland birds. Biological Conservation, 125(2), 225-235. https://doi.org/10.1016/j.biocon.2005.03.020

Gaston, K. J., Duffy, J. P., \& Bennie, J. (2015). Quantifying the erosion of natural darkness in the global protected area system. Conservation Biology, 29(4), 1132-1141. https://doi.org/10.1111/cobi.12462

Grill, A., \& Cleary, D. F. R. (2003). Diversity patterns in butterfly communities of the Greek nature reserve Dadia. Biological Conservation, 114(3), 427-436. https://doi.org/10.1016/S0006-3207(03)00070-3

Hoa Hong Dao, T., \& Hölscher, D. (2015). Red-Listed Tree Species Abundance in Montane Forest Areas with Differing Levels of Statutory Protection in North-Western Vietnam. Tropical Conservation Science, 8(2), 479-490. https://doi.org/10.1177/194008291500800212

Jusys, T. (2016). Quantifying avoided deforestation in Pará: Protected areas, buffer zones and edge effects. Journal for Nature Conservation, 33, 10-17. https://doi.org/10.1016/j.jnc.2016.05.001

Kintz, D. B., Young, K. R., \& Crews-Meyer, K. A. (2006). Implications of Land Use/Land Cover Change in the Buffer Zone of a National Park in the Tropical Andes. Environmental Management, 38(2), 238-252. https://doi.org/10.1007/s00267-005-0147-9

Krishna, A. P., Chhetri, S., \& Singh, K. K. (2006). Human Dimensions of Conservation in the Khangchendzonga Biosphere Reserve: The Need for Conflict Prevention. Mountain Research and Development, 22(4), 328-331. https://doi.org/10.1659/0276-4741(2002)022[0328:HDOCIT]2.0.CO;2 
Kuemmerle, T., Hostert, P., Radeloff, V. C., Perzanowski, K., \& Kruhlov, I. (2007). POST-SOCIALIST FOREST DISTURBANCE IN THE CARPATHIAN BORDER REGION OF POLAND, SLOVAKIA, AND UKRAINE. Ecological Applications, 17(5), 1279-1295. https://doi.org/10.1890/06-1661.1

Licona, M., McCleery, R., Collier, B., Brightsmith, D. J., \& Lopez, R. (2011). Using ungulate occurrence to evaluate community-based conservation within a biosphere reserve model. Animal Conservation, 14(2), 206-214. https://doi.org/10.1111/j.1469-1795.2010.00416.x

Mehring, M., \& Stoll-Kleemann, S. (2011). How effective is the buffer zone? linking institutional processes with satellite images from a case study in the Lore Lindu forest biosphere reserve, Indonesia. Ecology and Society, 16(4). https://doi.org/10.5751/ES-04349-160403

Nepal, S. K., \& Weber, K. E. (1994). A Buffer Zone for Biodiversity Conservation: Viability of the Concept in Nepal's Royal Chitwan National Park. Environmental Conservation, 21(04), 333. https://doi.org/10.1017/S0376892900033646

ORMSBY, A., \& KAPLIN, B. A. (2005). A framework for understanding community resident perceptions of Masoala National Park, Madagascar. Environmental Conservation, 32(02), 156. https://doi.org/10.1017/S0376892905002146

Sarker, A. H. M. R., \& Røskaft, E. (2011). Human attitudes towards the conservation of protected areas: a case study from four protected areas in Bangladesh. Oryx, 45(03), 391-400. https://doi.org/10.1017/S0030605310001067

Shyamsundar, P. (1996). Constraints on socio-buffering around the Mantadia National Park in Madagascar. Environmental Conservation, 23(01), 67. https://doi.org/10.1017/S0376892900038261

Weisse, M. J., \& Naughton-Treves, L. C. (2016). Conservation Beyond Park Boundaries: The Impact of Buffer Zones on Deforestation and Mining Concessions in the Peruvian Amazon. Environmental Management, 58(2), 297-311. https://doi.org/10.1007/s00267-016-0709-z

Xu, W., Li, X., Pimm, S. L., Hull, V., Zhang, J., Zhang, L., ... Ouyang, Z. (2016). The effectiveness of the zoning of China's protected areas. Biological Conservation, 204, 231-236. https://doi.org/10.1016/j.biocon.2016.10.028 